\title{
ONO-8430506: A Novel Autotaxin Inhibitor that Enhances the Antitumor Effect of Paclitaxel in a Breast Cancer Model
}

Yuzo Iwaki $,{ }^{*}, \dagger$ Akira Ohhata, ${ }^{\dagger}$ Shingo Nakatani,,${ }^{\dagger}$ Katsuya Hisaichi,,${ }^{\dagger}$ Yasuyuki Okabe,${ }^{\dagger}$ Atsushi Hiramatsu, ${ }^{\dagger}$ Toshihide Watanabe ${ }^{\dagger}$ Shingo Yamamoto, ${ }^{\dagger}$ Taihei Nishiyama, ${ }^{\dagger}$ Juta Kobayashi, ${ }^{\dagger}$ Yasuo Hirooka ${ }^{\dagger}$ Hideki Moriguchi, ${ }^{\#}$ Tatsuo Maeda, ${ }^{\ddagger}$ Makoto Katoh,,${ }^{\dagger}$ Yuka Komichi, $\$$ Hiroto Ota, ${ }^{\ddagger}$ Naoya Matsumura, ${ }^{\S}$ Masahiro Okada, ${ }^{\ddagger}$ Tetsuya Sugiyama, Hiroshi Saga, ${ }^{\star}$ and Akira Imagawa ${ }^{\dagger}$

${ }^{\dagger}$ Medicinal Chemistry Research Laboratories, ${ }^{\#}$ Chemical Process Research Laboratories, *Exploratory Research Laboratories, and \$Pharmaceutical Technology Laboratories, and "Pharmacokinetic Research Laboratories, Ono Pharmaceutical Co., Ltd., 3-1-1 Sakurai, Shimamoto-cho, Mishima-gun, Osaka 618-8585, Japan

Supporting Information

S2-S3: General Experimental

S4-9: Synthesis of Common Intermediates 28a-28d.

S10-S26: Synthesis of Carboxylic Acid Side Chains

S27-S41: Synthesis of Compound 1 and 3-20

S42-S45: Biology and DMPK 


\section{General Experimental}

Analytical samples were homogeneous as confirmed by TLC, and spectroscopic results were consistent with the assigned structures. NMR spectra were recorded as designated on either a Varian (Agilent) Mercury 300 spectrometer or Agilent VNMRS 600 spectrometer using deuterated chloroform $\left(\mathrm{CDCl}_{3}\right)$ or deuterated dimethyl sulfoxide $\left(\mathrm{DMSO}-\mathrm{d}_{6}\right)$ as the solvent. Fast atom bombardment (FAB) mass spectra and electron ionization (EI) mass spectra were obtained on a JEOL JMS-DX303HF spectrometer. Atmospheric pressure chemical ionization (APCI) mass spectra were obtained with a Hitachi M-1200H spectrometer. High resolution mass spectra (HRMS) were obtained on Thermo Fisher Scientific LTQ Orbitrap XL using electrospray ionization (ESI). Purity analysis was carried out by the following LC-MS system: Waters ACQUITY UPLC system fitted by with Waters Micromass ZQ-2000 spectrometer. Column; YMC Triart $\mathrm{C} 18(2.0 \mathrm{~mm} \times 30 \mathrm{~mm})$. Gradient condition; 5\% acetonitrile in $\mathrm{H}_{2} \mathrm{O}$ containing 0.1\%TFA (0-0.10 $\mathrm{min}), 5-95 \%(0.10-1.20 \mathrm{~min}), 95 \%$ (1.20-1.40 min). Flow rate of 1.0 $\mathrm{mL} / \mathrm{min}$, column temperature of $30{ }^{\circ} \mathrm{C}$, detection with UV (PDA) and ELSD. Column chromatography was performed with silica gel [Merck Silica Gel $60(0.063-0.200 \mu \mathrm{m})$, Wako gel C- 200 Fuji Silysia FL60D]. Thin layer chromatography was performed with silica gel (Merck TLC or HPTLC plates, Silica Gel 60 F254). All animal experiments were conducted in accordance with the internal regulations for care and use of laboratory animals by Ono Pharmaceutical Co., Ltd., and under the approval of the Ethics Committee for Animal Experiments of Ono Pharmaceutical Co., Ltd.

\section{The following abbreviations for solvents and reagents are used:}

benzylalcohol (BnOH); 1,2-dimethoxyethane (DME); $N, N$-dimethylformamide (DMF); dimethyl sulfoxide (DMSO); ethyl acetate (EtOAc); ethanol (EtOH); diisopropyl ether $\left(i-\mathrm{Pr}_{2} \mathrm{O}\right)$; acetonitrile $(\mathrm{MeCN})$; methanol $(\mathrm{MeOH})$; tert-butyl alcohol $(t-\mathrm{BuOH})$; tert-butyl methyl ether ( $t$-BuOMe); tetrahydrofuran (THF); silver acetate (AgOAc); 
2,2'-Azobis(isobutyronitrile) (AIBN); 1-ethyl-3-(3-dimethylaminopropyl) carbodiimide (EDC); triethylamine $\left(\mathrm{Et}_{3} \mathrm{~N}\right) ;$ hexamethylphosphoric triamide (HMPA); 1-hydroxybenzotriazole (HOBt); lithium diisopropylamide (LDA); trifluoroacetic acid (TFA); (trimethylsilyl)diazomethane $\left(\mathrm{TMSCHN}_{2}\right)$. 


\section{Synthesis of Common Intermediates 28a-28d}

\section{Scheme 1. Synthesis of 28a-28d}<smiles>Cc1cc2cccnc2[nH]1</smiles>

21

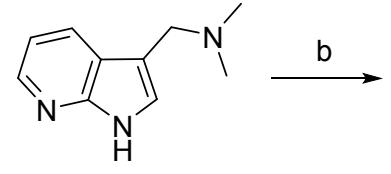

22

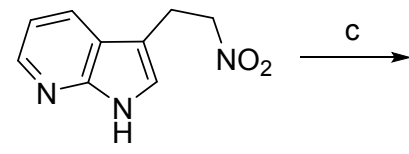

23<smiles>NCCc1c[nH]c2ncccc12</smiles>

24

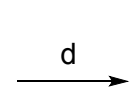<smiles>CNCCc1c(Cl)[nH]c2ncccc12</smiles>

25
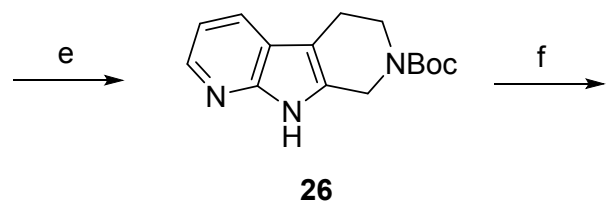
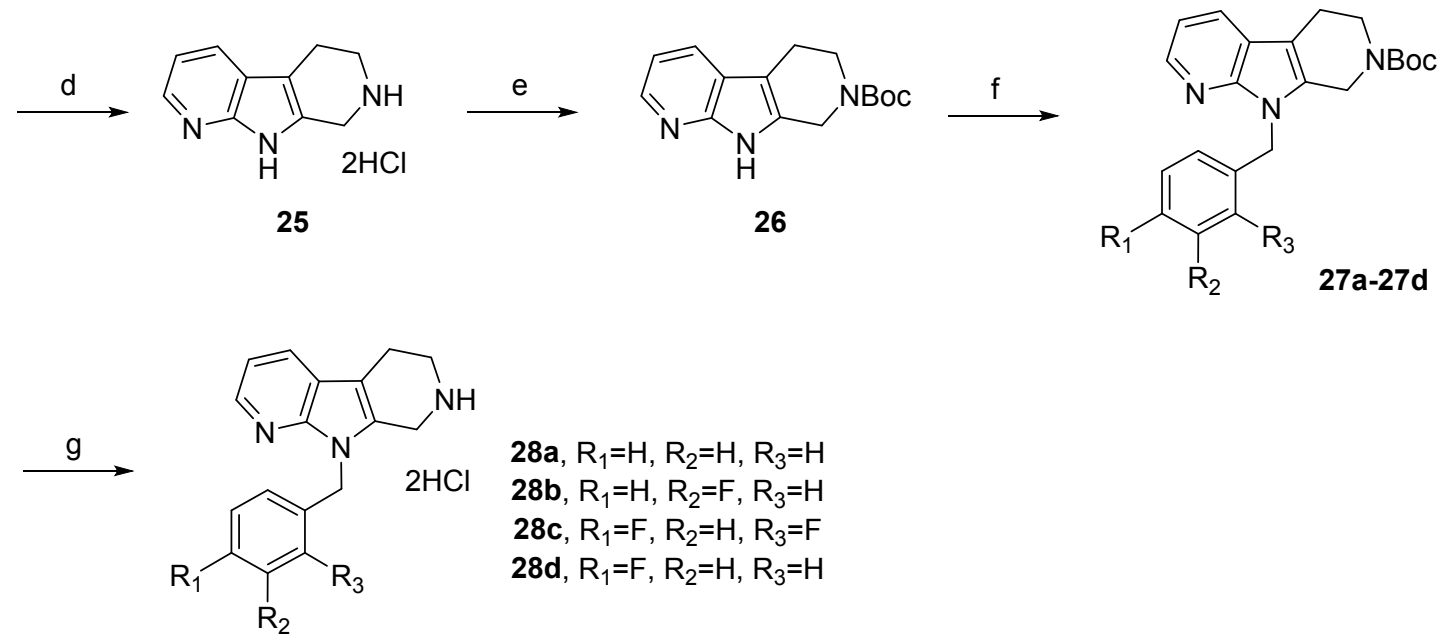

Reagents and conditions: (a) dimethylamine hydrochloride, $37 \% \mathrm{CH}_{2} \mathrm{O}$ aq., 1-butanol, reflux, 81\%; (b) nitromethane, dimethyl sulfate, $\mathrm{NaOMe}, \mathrm{MeOH}, \mathrm{rt}, 72 \%$; (c) $\mathrm{H}_{2}$, $\mathrm{Pd}(\mathrm{OH})_{2} / \mathrm{C}, \mathrm{EtOH}, 70^{\circ} \mathrm{C}, 95 \%$; (d) $\mathrm{HCl} / 1$,4-dioxane, $37 \% \mathrm{CH}_{2} \mathrm{O}$ aq., EtOH, reflux, 66\%; (e) $\mathrm{Boc}_{2} \mathrm{O}, \mathrm{NaOH}, 1,4-$ dioxane, rt, 58\%; (f) $\mathrm{ArCH}_{2} \mathrm{Br}$, NaH, DMF, rt, 69-90\%; (g) $\mathrm{HCl} / 1$,4-dioxane, rt, 90\%-quant.

\section{N,N-dimethyl-1-(1H-pyrrolo[2,3-b]pyridin-3-yl)methanamine (22)}

To a mixture of 21 (150 g, $1.27 \mathrm{~mol})$ and dimethylamine hydrochloride (114 g, 1.40 mol) in 1-butanol $(1.28 \mathrm{~L})$ was added a $37 \%$ aqueous formaldehyde solution (103 g). The resulting mixture was stirred at $120{ }^{\circ} \mathrm{C}$ for 2.5 hours. The reaction mixture was cooled to $40{ }^{\circ} \mathrm{C}$ and poured into $\mathrm{H}_{2} \mathrm{O}(1.35 \mathrm{~L})$. After concentrated hydrochloric acid (54 $\mathrm{mL})$ and $t$-BuOMe $(630 \mathrm{~mL})$ were added, the mixture was stirred and the layers were separated. The aqueous layer was further washed with $t$-BuOMe and $12 \mathrm{M} \mathrm{NaOH}$ was added. The aqueous layer was extracted with $\mathrm{CHCl}_{3}$ and a small amount of $\mathrm{MeOH}$ was 
added to the resulting organic layer. After the organic layer was dried over $\mathrm{MgSO}_{4}$, the filtrate was evaporated under reduced pressure to give 22 (179 g, $1.02 \mathrm{~mol})$ in 80\% yield. TLC: Rf $0.29\left(\mathrm{CHCl}_{3}: \mathrm{MeOH}: \mathrm{H}_{2} \mathrm{O}=50: 10: 1\right) ;{ }^{1} \mathrm{H}-\mathrm{NMR}\left(\mathrm{CDCl}_{3}\right): \delta 2.27(\mathrm{~s}, 6 \mathrm{H})$ $3.60(\mathrm{~s}, 2 \mathrm{H}) 7.08(\mathrm{dd}, J=8.0,5.0 \mathrm{~Hz}, 1 \mathrm{H}) 8.06(\mathrm{dd}, J=8.0,1.5 \mathrm{~Hz}, 1 \mathrm{H}) 8.31(\mathrm{dd}, J=$ $5.0,1.5 \mathrm{~Hz}, 1 \mathrm{H}) 9.80(\mathrm{~s}, 1 \mathrm{H})$.

\section{3-(2-nitroethyl)-1H-pyrrolo[2,3-b]pyridine (23)}

To a solution of $22(70.8 \mathrm{~g}, 0.40 \mathrm{~mol})$ in $\mathrm{MeOH}(600 \mathrm{~mL})$ and nitromethane $(600 \mathrm{~mL}$, $11.17 \mathrm{~mol})$, dimethyl sulfate $(42 \mathrm{~mL}, 0.44 \mathrm{~mol})$ was added for about 30 seconds at $6{ }^{\circ} \mathrm{C}$. After the mixture was stirred for about 4 minutes on an ice bath, stirring was kept for further 15 minutes at room temperature. Sodium methoxide $(28 \%$ in $\mathrm{MeOH}, 90.6 \mathrm{~mL}$, $0.42 \mathrm{~mol}$ ) was added dropwise for 14 minutes on an ice bath and the mixture was stirred for 1.5 hours. The precipitated pale yellowish white powder was filtered off and toluene $(600 \mathrm{~mL})$ was added to the filtrate. The filtrate was evaporated under reduced pressure to give a yellowish white paste, which was added EtOAc $(600 \mathrm{~mL})$ and aqueous saturated $\mathrm{NaHCO}_{3}(1.2 \mathrm{~L})$. After insoluble powder was filtered off, the mixture was extracted. The aqueous layer was extracted with EtOAc $(600 \mathrm{~mL})$ and the combined organic layers were washed with brine $(300 \mathrm{~mL})$. After the organic layer was dried over $\mathrm{NaSO}_{4}$, the filtrate was evaporated under reduced pressure to give $23(51.3 \mathrm{~g}, 0.27 \mathrm{~mol})$ in 68\% yield. TLC: Rf $0.68\left(\mathrm{CHCl}_{3}: \mathrm{MeOH}: \mathrm{H}_{2} \mathrm{O}=50: 10: 1\right) ;{ }^{1} \mathrm{H}-\mathrm{NMR}\left(\mathrm{CDCl}_{3}\right): \delta 3.49$ (t, $J=7.0 \mathrm{~Hz}, 2 \mathrm{H}) 4.67(\mathrm{t}, J=7.0 \mathrm{~Hz}, 2 \mathrm{H}) 7.12(\mathrm{dd}, J=8.0,5.0 \mathrm{~Hz}, 1 \mathrm{H}) 7.91(\mathrm{dd}, J=$ $8.0,1.5 \mathrm{~Hz}, 1 \mathrm{H}) 8.34(\mathrm{dd}, J=5.0,1.5 \mathrm{~Hz}, 1 \mathrm{H}) 9.60(\mathrm{~s}, 1 \mathrm{H})$.

\section{2-(1H-pyrrolo[2,3-b]pyridine-3-yl)ethanamine (24)}

To a suspension of 23 (114.9 g, $0.60 \mathrm{~mol})$ in $\mathrm{EtOH}(1.2 \mathrm{~L}), 20 \% \mathrm{Pd}(\mathrm{OH})_{2} / \mathrm{C}(50 \%$ wet, $57.7 \mathrm{~g}$ ) was added. The mixture was stirred for 16 hours at $70{ }^{\circ} \mathrm{C}$ under atmosphere of hydrogen. After the reaction mixture was cooled to room temperature, the catalyst was 
filtered off using Celite. The filtrate was concentrated under reduced pressure to give $\mathbf{2 4}$ $(99.6 \mathrm{~g})$. The crude product was used for the next reaction without further purification. TLC: Rf $0.14\left(\mathrm{CHCl}_{3}: \mathrm{MeOH}: \mathrm{H}_{2} \mathrm{O}=90: 10: 1\right) ;{ }^{1} \mathrm{H}-\mathrm{NMR}\left(\mathrm{CDCl}_{3}\right): \delta 2.89(\mathrm{t}, J=6.5 \mathrm{~Hz}$, 2H) $3.01(\mathrm{t}, J=7.0 \mathrm{~Hz}, 2 \mathrm{H}) 7.07(\mathrm{dd}, J=8.0,5.0 \mathrm{~Hz}, 1 \mathrm{H}) 7.15(\mathrm{~s}, 1 \mathrm{H}) 7.92(\mathrm{dd}, J=8.0$, $1.5 \mathrm{~Hz}, 1 \mathrm{H}) 8.29(\mathrm{dd}, J=5.0,1.5 \mathrm{~Hz}, 1 \mathrm{H}) 10.12(\mathrm{~s}, 1 \mathrm{H})$.

\section{6,7,8,9-tetrahydro-5H-pyrido $\left[4^{\prime}, 3^{\prime}: 4,5\right]$ pyrrolo[2,3-b]pyridine hydrochloride (25)}

To a solution of 25 (99.6 g, $0.60 \mathrm{~mol}$ from 24) in EtOH (2.9 L), 4 M HCl/1,4-dioxane solution $(150.5 \mathrm{~mL})$ and $37 \%$ aqueous formaldehyde solution $(53.7 \mathrm{~g})$ were added. After the mixture was heated to reflux for 3 hours, the mixture was cooled to below $40{ }^{\circ} \mathrm{C}$. The reaction mixture was diluted with $i-\operatorname{Pr}_{2} \mathrm{O}(3.4 \mathrm{~L})$ and $t$-BuOMe $(2.4 \mathrm{~L})$. The resulting solid was filtered off, washed with $t$-BuOMe $(500 \mathrm{~mL})$ and dried under reduced pressure to give $25(85.7 \mathrm{~g}, 0.41 \mathrm{~mol})$ in $68 \%$ yield (2 steps). TLC: Rf 0.27 $\left(\mathrm{CHCl}_{3}: \mathrm{MeOH}: 28 \%\right.$ aqueous $\left.\mathrm{NH}_{3}=90: 10: 1\right) ;{ }^{1} \mathrm{H}-\mathrm{NMR}\left(\mathrm{CDCl}_{3}\right): \delta 2.94(\mathrm{t}, J=6.0 \mathrm{~Hz}$, 2H) 3.40-3.44 (m, 2H) $4.33(\mathrm{~s}, 2 \mathrm{H}), 7.14(\mathrm{dd}, J=8.0,5.0 \mathrm{~Hz}, 1 \mathrm{H}) 8.01(\mathrm{dd}, J=8.0,1.5$ $\mathrm{Hz}, 1 \mathrm{H}) 8.23(\mathrm{dd}, J=5.0,1.5 \mathrm{~Hz}, 1 \mathrm{H}) 9.75(\mathrm{~s}, 2 \mathrm{H}), 11.87(\mathrm{~s}, 1 \mathrm{H})$.

\section{Tert-butyl 5,6,8,9-tetrahydro-7H-pyrido[4',3':4,5]pyrrolo[2,3-b]pyridine-7-carbox ylate (26)}

To a suspension of 25 (95.9 g, $0.46 \mathrm{~mol})$ in 1,4-dioxane (1.94 L), $1 \mathrm{M} \mathrm{NaOH}(480 \mathrm{~mL}$, $0.48 \mathrm{~mol}$ ) was added. After the mixture was cooled on an ice bath, di-tert-butyl dicarbonate $(104.8 \mathrm{~g}, 0.48 \mathrm{~mol})$ was added. The mixture was stirred for 12.5 hours at room temperature and the reaction mixture was poured into aqueous saturated $\mathrm{NaHCO}_{3}$ (6 L), followed by extraction with EtOAc (2 L) three times. The combined organic layers were washed with brine $(2 \mathrm{~L})$, dried with anhydrous $\mathrm{Na}_{2} \mathrm{SO}_{4}$ and concentrated under reduced pressure. The residue was purified by silica gel column chromatography (EtOAc) to give the product. $n$-Hexane $(880 \mathrm{~mL})$ was added to the product and it was 
allowed to stand overnight at room temperature. The resulting solid was filtered off, washed with $n$-hexane/EtOAc $(10 / 1,150 \mathrm{~mL})$ and dried at room temperature under reduced pressure to give $26(72.1 \mathrm{~g}, 0.26 \mathrm{~mol})$ in $57 \%$ yield. TLC: Rf 0.60 $\left(\mathrm{CHCl}_{3}: \mathrm{MeOH}: 28 \%\right.$ aqueous $\left.\mathrm{NH}_{3}=90: 10: 1\right) ;{ }^{1} \mathrm{H}-\mathrm{NMR}\left(\mathrm{CDCl}_{3}\right): \delta 1.51(\mathrm{~s}, 9 \mathrm{H}), 2.79(\mathrm{t}$, $J=6.0 \mathrm{~Hz}, 2 \mathrm{H}) 3.79(\mathrm{t}, J=6.0 \mathrm{~Hz}, 2 \mathrm{H}) 4.71(\mathrm{~s}, 2 \mathrm{H}), 7.05(\mathrm{dd}, J=8.0,5.0 \mathrm{~Hz}, 1 \mathrm{H}) 7.79$ $(\mathrm{m}, 1 \mathrm{H}) 8.23(\mathrm{~m}, 1 \mathrm{H}) 10.10-10.75(\mathrm{~m}, 1 \mathrm{H})$.

\section{2-methyl-2-propanyl 9-(3-fluorobenzyl)-5,6,8,9-tetrahydro-7H-pyrido[4',3' :4,5]pyr rolo[2,3-b]pyridine-7-carboxylate (27b)}

To a solution of 26 (450 mg, $1.65 \mathrm{mmol})$ in DMF (5 mL), sodium hydride (60\% in oil, $69 \mathrm{mg}, 1.73 \mathrm{mmol}$ ) was added at $0{ }^{\circ} \mathrm{C}$. After the mixture was stirred for 30 minutes at room temperature, 1-(bromomethyl)-3-fluorobenzene (373 mg, $1.97 \mathrm{mmol}$ ) was added. The reaction mixture was stirred for 4 hours and quenched with aqueous saturated $\mathrm{NaHCO}_{3}$ and $\mathrm{H}_{2} \mathrm{O}$ followed by extraction with $n$-hexane/EtOAc (10/1). The organic layer was washed with $\mathrm{H}_{2} \mathrm{O}$ (two times) and brine, dried with anhydrous $\mathrm{MgSO}_{4}$ and concentrated under reduced pressure. The residue was purified by silica gel column chromatography ( $n$-hexane:EtOAc $=95: 5$ to $90: 10$ to $80: 20)$ to give $27 \mathbf{b}(481 \mathrm{mg}, 1.26$ mmol) in 77\% yield. TLC: Rf 0.65 (n-hexane:EtOAc $=75: 25) ;{ }^{1} \mathrm{H}-\mathrm{NMR}\left(\mathrm{CDCl}_{3}\right): \delta$ $1.46(\mathrm{~s}, 9 \mathrm{H}), 2.75-2.84(\mathrm{~m}, 2 \mathrm{H}) 3.66-3.80(\mathrm{~m}, 2 \mathrm{H}) 4.48(\mathrm{~s}, 2 \mathrm{H}), 5.43(\mathrm{~s}, 2 \mathrm{H}), 6.74-6.83$ (m, 1H), 6.86-6.98 (m, 2H), 7.08 (dd, $J=7.9,4.8 \mathrm{~Hz}, 1 \mathrm{H}), 7.19-7.29$ (m, 1H), 7.80 (dd, $J=7.8,1.4 \mathrm{~Hz}, 1 \mathrm{H}), 8.29(\mathrm{dd}, J=4.8,1.5 \mathrm{~Hz}, 1 \mathrm{H})$.

\section{9-(3-fluorobenzyl)-6,7,8,9-tetrahydro-5H-pyrido[4',3':4,5]pyrrolo[2,3-b]pyridine dihydrochloride (28b)}

To a solution of $\mathbf{2 7 b}(470 \mathrm{mg}, 1.23 \mathrm{mmol})$ in 1,4-dioxane $(3 \mathrm{~mL}), 4 \mathrm{M}$ $\mathrm{HCl} / 1$,4-dioxane solution ( $3 \mathrm{~mL}$ ) was added. After the mixture was stirred for 3 hours at room temperature, $\mathrm{CH}_{2} \mathrm{Cl}_{2}(3 \mathrm{~mL})$ was added and the reaction mixture was stirred for 5 
hours. $i-\operatorname{Pr}_{2} \mathrm{O}(10 \mathrm{~mL})$ was added to the reaction mixture and the precipitate was filtered off to give $\mathbf{2 8 b}$ (423 mg, $1.19 \mathrm{mmol}$ ) in 97\% yield. ${ }^{1} \mathrm{H}-\mathrm{NMR}$ (DMSO- $d_{6}$ ): $\delta 2.91-3.02$ $(\mathrm{m}, 2 \mathrm{H}), 3.36-3.47(\mathrm{~m}, 2 \mathrm{H}), 4.26-4.36(\mathrm{~m}, 2 \mathrm{H}), 5.50(\mathrm{~s}, 2 \mathrm{H}), 6.91-7.01(\mathrm{~m}, 2 \mathrm{H})$, 7.03-7.12 (m, 1H), 7.16 (dd, $J=7.7,4.8 \mathrm{~Hz}, 1 \mathrm{H}), 7.29-7.39$ (m, 1H), 7.99 (dd, $J=7.9$, $1.5 \mathrm{~Hz}, 1 \mathrm{H}), 8.27(\mathrm{dd}, J=4.8,1.5 \mathrm{~Hz}, 1 \mathrm{H})$.

27a, 27c-d, 28a, and 28c-d were synthesized in the same procedure.

2-methyl-2-propanyl 9-benzyl-5,6,8,9-tetrahydro-7H-pyrido[4',3':4,5]pyrrolo[2,3-b Ipyridine-7-carboxylate (27a)

TLC: Rf $0.90(n$-hexane:EtOAc $=33: 67) ;{ }^{1} \mathrm{H}-\mathrm{NMR}\left(\mathrm{CDCl}_{3}\right): \delta 1.45(\mathrm{~s}, 9 \mathrm{H}), 2.73-2.84$ (m, 2H), 3.65-3.79 (m, 2H), $4.48(\mathrm{~s}, 2 \mathrm{H}), 5.45(\mathrm{~s}, 2 \mathrm{H}), 7.07(\mathrm{dd}, J=7.9,4.8 \mathrm{~Hz}, 1 \mathrm{H})$, 7.10-7.39 (m, 5H), $7.80(\mathrm{dd}, J=7.8,1.2 \mathrm{~Hz}, 1 \mathrm{H}), 8.30$ (dd, $J=4.8,1.5 \mathrm{~Hz}, 1 \mathrm{H})$.

2-methyl-2-propanyl 9-(2,4-difluorobenzyl)-5,6,8,9-tetrahydro-7H-pyrido[4',3':4,5] pyrrolo[2,3-b]pyridine-7-carboxylate (27c)

TLC: Rf 0.47 ( $n$-hexane:EtOAc $=80: 20) ;{ }^{1} \mathrm{H}-\mathrm{NMR}\left(\mathrm{CDCl}_{3}\right): \delta 1.47(\mathrm{~s}, 9 \mathrm{H}), 2.74-2.84$ $(\mathrm{m}, 2 \mathrm{H}), 3.68-3.80(\mathrm{~m}, 2 \mathrm{H}), 4.52(\mathrm{~s}, 2 \mathrm{H}), 5.44(\mathrm{~s}, 2 \mathrm{H}), 6.66-7.03(\mathrm{~m}, 3 \mathrm{H}), 7.07(\mathrm{dd}, J=$ 7.9, $4.8 \mathrm{~Hz}, 1 \mathrm{H}), 7.79$ (dd, $J=7.8,1.4 \mathrm{~Hz}, 1 \mathrm{H}), 8.28$ (dd, $J=4.8,1.3 \mathrm{~Hz}, 1 \mathrm{H})$.

2-methyl-2-propanyl 9-(4-fluorobenzyl)-5,6,8,9-tetrahydro-7H-pyrido[4',3' :4,5]pyr rolo[2,3-b]pyridine-7-carboxylate (27d)

TLC: Rf 0.34 ( $n$-hexane:EtOAc $=80: 20) ;{ }^{1} \mathrm{H}-\mathrm{NMR}\left(\mathrm{CDCl}_{3}\right): \delta 1.46(\mathrm{~s}, 9 \mathrm{H}), 2.73-2.83$ $(\mathrm{m}, 2 \mathrm{H}) 3.65-3.79(\mathrm{~m}, 2 \mathrm{H}), 4.48(\mathrm{~s}, 2 \mathrm{H}), 5.41(\mathrm{~s}, 2 \mathrm{H}), 6.89-7.02(\mathrm{~m}, 2 \mathrm{H}), 7.04-7.17(\mathrm{~m}$, $3 \mathrm{H}), 7.79(\mathrm{dd}, J=7.8,1.3 \mathrm{~Hz}, 1 \mathrm{H}), 8.29(\mathrm{dd}, J=4.8,1.5 \mathrm{~Hz}, 1 \mathrm{H})$.

9-benzyl-6,7,8,9-tetrahydro-5H-pyrido $\left[4^{\prime}, 3^{\prime}: 4,5\right]$ pyrrolo $[2,3-b] p y r i d i n e ~ d i h y d r o c h l$ oride (28a) 
${ }^{1} \mathrm{H}-\mathrm{NMR}\left(\mathrm{DMSO}-d_{6}\right): \delta 2.91-3.01(\mathrm{~m}, 2 \mathrm{H}), 3.35-3.50(\mathrm{~m}, 2 \mathrm{H}), 4.25-4.36(\mathrm{~m}, 2 \mathrm{H}), 5.48$ (s, 2H), 7.11-7.19 (m, 3H), 7.20-7.37 (m, 3H), 7.98 (dd, $J=7.8,1.4 \mathrm{~Hz}, 1 \mathrm{H}), 8.28(\mathrm{dd}, J$ $=4.7,1.6 \mathrm{~Hz}, 1 \mathrm{H}), 9.52-9.86(\mathrm{~m}, 2 \mathrm{H})$.

9-(2,4-difluorobenzyl)-6,7,8,9-tetrahydro-5H-pyrido[4',3' :4,5]pyrrolo[2,3-b]pyridi ne dihydrochloride (28c)

${ }^{1} \mathrm{H}-\mathrm{NMR}\left(\mathrm{DMSO}-d_{6}\right): \delta$ 2.91-3.01 (m, 2H), 3.35-3.47 (m, 2H), 4.28-4.38 (m, 2H), 5.28 (s, 2H), 6.92-7.11 (m, 2H), 7.16 (dd, $J=7.9,4.8 \mathrm{~Hz}, 1 \mathrm{H}), 7.22-7.33(\mathrm{~m}, 1 \mathrm{H}), 8.00(\mathrm{dd}, J$ $=7.7,1.5 \mathrm{~Hz}, 1 \mathrm{H}), 8.26(\mathrm{dd}, J=4.9,1.6 \mathrm{~Hz}, 1 \mathrm{H}), 9.80-10.04(\mathrm{~m}, 2 \mathrm{H})$.

9-(4-fluorobenzyl)-6,7,8,9-tetrahydro-5H-pyrido[4',3':4,5]pyrrolo[2,3-b]pyridine dihydrochloride (28d)

${ }^{1} \mathrm{H}-\mathrm{NMR}\left(\mathrm{DMSO}-d_{6}\right): \delta$ 2.85-3.08 (m, 2H), 3.32-3.48 (m, 2H), 4.25-4.35 (m, 2H), 5.51 (s, 2H), 7.07-7.30 (m, 5H), $8.05(\mathrm{dd}, J=7.8,1.4 \mathrm{~Hz}, 1 \mathrm{H}), 8.30(\mathrm{dd}, J=4.8,1.3 \mathrm{~Hz}, 1 \mathrm{H})$, 9.91-10.19 (m, 2H). 


\section{Synthesis of Carboxylic Acid Side Chains}

\section{Scheme 2. Synthesis of 33}<smiles>BrCCCCOCc1ccccc1</smiles>

29

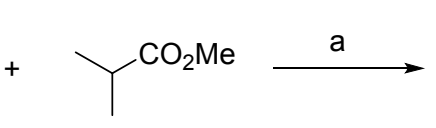

30

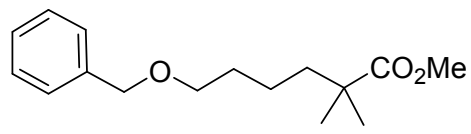

31

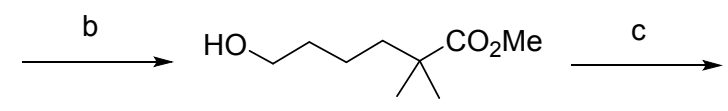

32

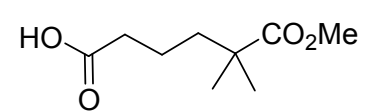

33

Reagents and conditions: (a) LDA, THF, rt, 42\%; (b) $\mathrm{H}_{2}, \mathrm{Pd} / \mathrm{C}, \mathrm{HCl} / 1$,4-dioxane, $\mathrm{MeOH}, \mathrm{rt}, 66 \%$; (c) $\mathrm{NaIO}_{4}, \mathrm{RuCl}_{3}, \mathrm{CCl}_{4} / \mathrm{MeCN} / \mathrm{H}_{2} \mathrm{O}$, rt, $96 \%$.

\section{Methyl 6-(benzyloxy)-2,2-dimethylhexanoate (31)}

To a solution of $\mathbf{3 0}(25.6 \mathrm{~g}, 251 \mathrm{mmol})$ in THF $(250 \mathrm{~mL})$, LDA $(2.0 \mathrm{M}$ in THF/ethylbenzene/heptane, $134 \mathrm{~mL}, 267 \mathrm{mmol}$ ) was added for 10 minutes at room temperature. The mixture was stirred for 30 minutes at room temperature to prepare lithium enolate of 30. To this enolate, $29(40.6 \mathrm{~g}, 167 \mathrm{mmol})$ was added and the mixture was stirred at room temperature for 1 hour. To the reaction mixture, the lithium enolate prepared from $30(3.5 \mathrm{~g}, 34.3 \mathrm{mmol})$ and LDA $(2.0 \mathrm{M}$ in THF/ethylbenzene/heptane, $18.3 \mathrm{~mL}, 36.6 \mathrm{mmol}$ ) as above was added. After the mixture was stirred at room temperature overnight, saturated aqueous $\mathrm{NaHCO}_{3}$ was added, which was extracted with EtOAc. The organic layer was washed with $1 \mathrm{M} \mathrm{HCl}, \mathrm{H}_{2} \mathrm{O}$ and brine. After the organic layer was dried with anhydrous $\mathrm{MgSO}_{4}$ and concentrated under reduced pressure, the residue was purified by silica gel column chromatography ( $n$-hexane:EtOAc $=97: 3$ to $95: 5)$ to give $31(18.4 \mathrm{~g}, 69.6 \mathrm{mmol})$ in $42 \%$ yield. TLC: $\mathrm{Rf}$ $0.41(n$-hexane:EtOAc $=90: 10) ;{ }^{1} \mathrm{H}-\mathrm{NMR}\left(\mathrm{CDCl}_{3}\right): \delta 1.16(\mathrm{~s}, 6 \mathrm{H}), 1.23-1.40(\mathrm{~m}, 2 \mathrm{H})$, 1.49-1.65 (m, 4H), $3.45(\mathrm{t}, J=6.6 \mathrm{~Hz}, 2 \mathrm{H}), 3.65(\mathrm{~s}, 3 \mathrm{H}), 4.49(\mathrm{~s}, 2 \mathrm{H}), 7.23-7.38(\mathrm{~m}$, $5 \mathrm{H})$. 


\section{Methyl 6-hydroxy-2,2-dimethylhexanoate (32)}

To a solution of 31 (18.4 g, $69.6 \mathrm{mmol})$ in $\mathrm{MeOH}(200 \mathrm{~mL}), 4 \mathrm{~N} \mathrm{HCl} / 1$,4-dioxane solution $(20 \mathrm{~mL})$ and $10 \% \mathrm{Pd} / \mathrm{C}(50 \%$ wet, $1.84 \mathrm{~g})$ were added. The reaction mixture was stirred for 4 hours under atmosphere of hydrogen at $50{ }^{\circ} \mathrm{C}$. After the reaction mixture was cooled to room temperature, the catalyst was filtered off using Celite and the filtrate was concentrated under reduced pressure. Toluene was added to the residue and the resulting mixture was concentrated under reduced pressure (two times). The residue was purified by silica gel column chromatography ( $n$-hexane:EtOAc $=90: 10$ to 60:40) to give $32(8.04 \mathrm{~g}, 46.1 \mathrm{mmol})$ in 66\% yield. TLC: Rf 0.13 ( $n$-hexane:EtOAc $=$ 80:20). ${ }^{1} \mathrm{H}-\mathrm{NMR}\left(\mathrm{CDCl}_{3}\right): \delta 1.17(\mathrm{~s}, 6 \mathrm{H}), 1.22-1.39(\mathrm{~m}, 2 \mathrm{H}), 1.46-1.63(\mathrm{~m}, 4 \mathrm{H})$, 3.60-3.67 (m, 5H).

\section{6-methoxy-5,5-dimethyl-6-oxohexanoic acid (33)}

To a solution of $32(7.0 \mathrm{~g}, 40.2 \mathrm{mmol})$ in carbon tetrachloride $(50 \mathrm{~mL}), \mathrm{H}_{2} \mathrm{O}(75 \mathrm{~mL})$ and $\mathrm{MeCN}(50 \mathrm{~mL})$, sodium periodate $(19.3 \mathrm{~g}, 90.2 \mathrm{mmol})$ and ruthenium trichloride hydrate $(716 \mathrm{mg})$ were added. After the reaction mixture was stirred for 3 hours at room temperature, $\mathrm{H}_{2} \mathrm{O}$ was added ant the mixture was extracted with EtOAc. The organic layer was washed with $\mathrm{H}_{2} \mathrm{O}$ and brine, dried with anhydrous $\mathrm{MgSO}_{4}$ and concentrated under reduced pressure. The residue was purified by silica gel column chromatography ( $n$-hexane:EtOAc $=80: 20$ to $50: 50)$ to give $33(7.3 \mathrm{~g}, 38.7 \mathrm{mmol}$ ) in 96\% yield. TLC: Rf $0.36(n$-hexane:EtOAc $=1: 1) ;{ }^{1} \mathrm{H}-\mathrm{NMR}\left(\mathrm{CDCl}_{3}\right): \delta 1.18(\mathrm{~s}, 6 \mathrm{H}), 1.51-1.64(\mathrm{~m}, 4 \mathrm{H})$, 2.30-2.39 (m, 2H), $3.66(\mathrm{~s}, 3 \mathrm{H})$.

\section{Scheme 3. Synthesis of 38}


<smiles>CC1(C)CC(=O)OC(=O)C1</smiles>

34

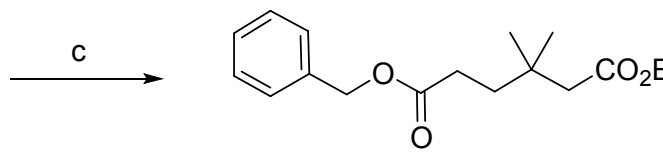

37

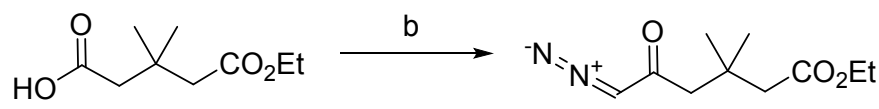

35
36<smiles>CCOCCC(C)(C)CCC(=O)O</smiles>

38

Reagents and conditions: (a) EtOH, $100{ }^{\circ} \mathrm{C}, 55 \%$; (b) $\mathrm{SOCl}_{2}$, DMF, EtOAc, $60{ }^{\circ} \mathrm{C}$ then $\mathrm{TMSCHN}_{2}, \mathrm{THF} / \mathrm{MeCN}, 0{ }^{\circ} \mathrm{C}$ to rt, $71 \%$; (c) $\mathrm{AgOAc}, \mathrm{Et}_{3} \mathrm{~N}, \mathrm{BnOH}$, rt to $60{ }^{\circ} \mathrm{C}, 82 \%$; (d) $\mathrm{H}_{2}, \mathrm{Pd} / \mathrm{C}, \mathrm{EtOH}, \mathrm{rt}, 91 \%$.

\section{5-ethoxy-3,3-dimethyl-5-oxopentanoic acid (35)}

The mixture of $34(7.11 \mathrm{~g}, 50.0 \mathrm{mmol})$ and $\mathrm{EtOH}(50 \mathrm{~mL})$ was stirred for 18 hours at $100{ }^{\circ} \mathrm{C}$. After the reaction mixture was cooled to room temperature, the mixture was concentrated under reduced pressure. The reaction mixture was diluted with EtOAc and extracted with an aqueous saturated $\mathrm{NaHCO}_{3}$ (two times). To the combined aqueous layers was added $5 \mathrm{M} \mathrm{HCl}$ to make the layers acidic, which were extracted with EtOAc. The organic layer was dried with anhydrous $\mathrm{MgSO}_{4}$ and concentrated under reduced pressure. The residue was purified by silica gel column chromatography ( $n$-hexane:EtOAc $=80: 20$ to $60: 40)$ to give $35(5.15 \mathrm{~g}, 27.4 \mathrm{mmol})$ in $55 \%$ yield. TLC: Rf $0.39(n$-hexane:EtOAc $=67: 34) ;{ }^{1} \mathrm{H}-\mathrm{NMR}\left(\mathrm{CDCl}_{3}\right): \delta 1.14(\mathrm{~s}, 6 \mathrm{H}), 1.27(\mathrm{t}, J=7.1$ $\mathrm{Hz}, 3 \mathrm{H}), 2.43$ (s, 2H), 2.47 (s, 2H), 4.15 (q, $J=7.1 \mathrm{~Hz}, 2 \mathrm{H})$.

\section{Ethyl 6-diazo-3,3-dimethyl-5-oxohexanoate (36)}

To a solution of 35 (1.50 g, $7.97 \mathrm{mmol})$ in EtOAc (13.3 mL), $\mathrm{SOCl}_{2}(7.32 \mathrm{~mL}, 100.3$ mmol) and DMF (0.05 mL) were added. The reaction mixture was stirred for 8.5 hours at $60{ }^{\circ} \mathrm{C}$. After the mixture was cooled to room temperature, the mixture was 
concentrated under reduced pressure. Toluene was added to the residue and the resulting mixture was concentrated under reduced pressure (three times). The resulting acid chloride in $\mathrm{THF} / \mathrm{MeCN}(1 / 1,6 \mathrm{~mL})$ were added to a solution of $\mathrm{TMSCHN}_{2}(2.0 \mathrm{M}$ in hexane, $8.8 \mathrm{~mL}, 17.5 \mathrm{mmol})$ in $\mathrm{THF} / \mathrm{MeCN}(1 / 1,15 \mathrm{~mL})$ at $0{ }^{\circ} \mathrm{C}$. After the reaction mixture was stirred for 1 hour, the mixture was raised to room temperature. The mixture was stirred for 1 hour at room temperature and it was concentrated under reduced pressure. The residue was purified by silica gel column chromatography ( $n$-hexane:EtOAc $=90: 10$ to $70: 30)$ to give $\mathbf{3 6}(1.21 \mathrm{~g}, 5.70 \mathrm{mmol})$ in $71 \%$ yield. TLC: Rf $0.28(n$-hexane:EtOAc $=80: 20) ;{ }^{1} \mathrm{H}-\mathrm{NMR}\left(\mathrm{CDCl}_{3}\right): \delta 1.12(\mathrm{~s}, 6 \mathrm{H}), 1.26(\mathrm{t}, J=7.1$ $\mathrm{Hz}, 3 \mathrm{H}), 2.34-2.47$ (m, 4H), 4.13 (q, $J=7.1 \mathrm{~Hz}, 2 \mathrm{H}), 5.38(\mathrm{~s}, 1 \mathrm{H})$.

\section{6-benzyl 1-ethyl 3,3-dimethylhexanedioate (37)}

To a solution of $36(1.06 \mathrm{~g}, 4.97 \mathrm{mmol})$ in $\mathrm{BnOH}(5.0 \mathrm{~mL}), \mathrm{Et}_{3} \mathrm{~N}(1.39 \mathrm{~mL}, 9.94$ mmol) and AgOAc (17 mg, $0.099 \mathrm{mmol})$ were added. After the reaction mixture was stirred for 15 minutes at room temperature, the mixture was raised to $60{ }^{\circ} \mathrm{C}$ and stirred for 1 hour. The mixture was cooled to room temperature and quenched with $1 \mathrm{M} \mathrm{HCl}$, which was extracted with $n$-hexane $(30 \mathrm{~mL})$. The organic layer was washed with $1 \mathrm{M}$ $\mathrm{HCl}$ (two times) and brine, dried with anhydrous $\mathrm{MgSO}_{4}$ and concentrated under reduced pressure. The residue was purified by silica gel column chromatography ( $n$-hexane:EtOAc $=100: 0$ to $90: 10$ to $85: 15)$ to give $37(1.19 \mathrm{~g}, 4.07 \mathrm{mmol})$ in $82 \%$ yield. TLC: Rf 0.60 (n-hexane:EtOAc $=80: 20) ;{ }^{1} \mathrm{H}-\mathrm{NMR}\left(\mathrm{CDCl}_{3}\right): \delta 1.00(\mathrm{~s}, 6 \mathrm{H}), 1.24$ $(\mathrm{t}, J=7.1 \mathrm{~Hz}, 3 \mathrm{H}), 1.65-1.76(\mathrm{~m}, 2 \mathrm{H}), 2.18(\mathrm{~s}, 2 \mathrm{H}), 2.32-2.44(\mathrm{~m}, 2 \mathrm{H}), 4.11(\mathrm{q}, J=7.1$ $\mathrm{Hz}, 2 \mathrm{H}), 5.11(\mathrm{~s}, 2 \mathrm{H}), 7.28-7.41(\mathrm{~m}, 5 \mathrm{H})$.

\section{6-ethoxy-4,4-dimethyl-6-oxohexanoic acid (38)}

To a solution of 37 (728 mg, $2.49 \mathrm{mmol})$ in $\mathrm{EtOH}(8.3 \mathrm{~mL}), 5 \% \mathrm{Pd} / \mathrm{C}$ (50\% wet, 73 $\mathrm{mg}$ ) was added. The reaction mixture was stirred for 1.5 hours under atmosphere of 
hydrogen at room temperature. After the catalyst was filtered off using Celite, the filtrate was concentrated under reduced pressure to give $38(459 \mathrm{mg}, 2.27 \mathrm{mmol})$ in 91\% yield. TLC: Rf 0.39 (n-hexane:EtOAc $=67: 34) ;{ }^{1} \mathrm{H}-\mathrm{NMR}\left(\mathrm{CDCl}_{3}\right): \delta 1.02(\mathrm{~s}, 6 \mathrm{H})$, $1.26(\mathrm{t}, J=7.1 \mathrm{~Hz}, 3 \mathrm{H}), 1.63-1.76(\mathrm{~m}, 2 \mathrm{H}), 2.20(\mathrm{~s}, 2 \mathrm{H}), 2.31-2.44(\mathrm{~m}, 2 \mathrm{H}), 4.12(\mathrm{q}, J=$ $7.1 \mathrm{~Hz}, 2 \mathrm{H})$.

\section{Scheme 4. Synthesis of 42}
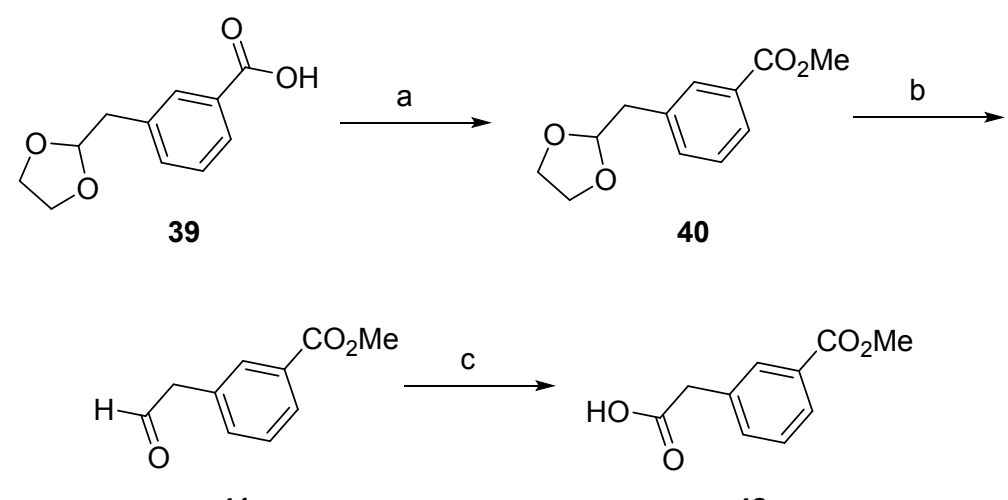

41

42

Reagents and conditions: (a) $\mathrm{TMSCHN}_{2}, \mathrm{MeOH}$, rt, 99\%; (b) $2 \mathrm{M} \mathrm{HCl}, 50{ }^{\circ} \mathrm{C}$; (c) $\mathrm{NaClO}_{2}, \mathrm{NaH}_{2} \mathrm{PO}_{4}, 2$-methyl-2-butene, $t$-BuOH/THF/H ${ }_{2} \mathrm{O}, \mathrm{rt}, 81 \%$ (2 steps).

\section{Methyl 3-(1,3-dioxolan-2-ylmethyl)benzoate (40)}

To a solution of 39 (500 mg, $2.40 \mathrm{mmol})$ in $\mathrm{MeOH}(7 \mathrm{~mL})$ was added $\mathrm{TMSCHN}_{2}(2.0$ $\mathrm{M}$ in hexanes, $4.8 \mathrm{~mL}, 9.60 \mathrm{mmol}$ ) at $0{ }^{\circ} \mathrm{C}$ and the mixture was stirred at room temperature for 3.5 hours. After the reaction mixture was concentrated under reduced pressure, the residue was purified by column chromatography ( $n$-hexane: EtOAc $=90: 10$ to $70: 30)$ to give $\mathbf{4 0}(531 \mathrm{mg}, 9.50 \mathrm{mmol})$ in $99 \%$ yield. TLC: Rf 0.32 ( $n$-hexane:EtOAc $=80: 20) ;{ }^{1} \mathrm{H}-\mathrm{NMR}\left(\mathrm{CDCl}_{3}\right): \delta 3.02(\mathrm{~d}, J=4.8 \mathrm{~Hz}, 2 \mathrm{H}), 3.81-3.97(\mathrm{~m}$, 4H), $5.09(\mathrm{t}, J=4.8 \mathrm{~Hz}, 1 \mathrm{H}), 7.38(\mathrm{t}, J=7.4 \mathrm{~Hz}, 1 \mathrm{H}), 7.47-7.52(\mathrm{~m}, 1 \mathrm{H}), 7.94-7.99(\mathrm{~m}$, $2 \mathrm{H})$. 


\section{Methyl 3-(2-oxoethyl)benzoate (41)}

The mixture of $40(248 \mathrm{mg}, 1.12 \mathrm{mmol})$ in $1 \mathrm{M}$ sulfuric acid was stirred at $50{ }^{\circ} \mathrm{C}$ for 2 hours. After the reaction mixture was cooled to room temperature, aqueous saturated $\mathrm{NaHCO}_{3}$ was added to the mixture, which was extracted with EtOAc (two times). The combined organic layers were washed with brine, dried with anhydrous $\mathrm{Na}_{2} \mathrm{SO}_{4}$ and concentrated to give 41 (234 mg) as a crude product. The crude product was used for the next reaction without further purification.

\section{[3-(methoxycarbonyl)phenyl]acetic acid (42)}

To the mixture of 41 (234 mg, $1.12 \mathrm{mmol}$ from 40) and 2-methyl-2-butene (2.37 mL, $22.3 \mathrm{mmol})$ in $t$-BuOH$/ \mathrm{THF} / \mathrm{H}_{2} \mathrm{O}(11 \mathrm{~mL}, 3 / 3 / 1), \mathrm{NaClO}_{2}(303 \mathrm{mg}, 3.35 \mathrm{mmol})$ and $\mathrm{NaH}_{2} \mathrm{PO}_{4}(870 \mathrm{mg}, 5.58 \mathrm{mmol})$ were added at $0{ }^{\circ} \mathrm{C}$. After the reaction mixture was stirred at room temperature for 40 minutes, the mixture was concentrated under reduced pressure. Aqueous saturated $\mathrm{NaHCO}_{3}$ was added to the residue and the mixture was extracted with $t$-BuOMe. To the resulting aqueous layer, $2 \mathrm{M} \mathrm{HCl}$ was added and it was extracted with EtOAc. The organic layer was washed with brine, dried with anhydrous $\mathrm{Na}_{2} \mathrm{SO}_{4}$ and concentrated to give 42 (175 mg, $\left.0.91 \mathrm{mmol}\right)$ in 81\% (2 steps). TLC: Rf 0.35 (EtOAc); ${ }^{1} \mathrm{H}-\mathrm{NMR}\left(\mathrm{CDCl}_{3}\right): \delta 3.72(\mathrm{~s}, 2 \mathrm{H}), 3.92(\mathrm{~s}, 3 \mathrm{H}), 7.42(\mathrm{t}, J=7.4 \mathrm{~Hz}, 1 \mathrm{H})$, 7.45-7.51 (m, 1H), 7.88-7.98 (m, 2H).

\section{Scheme 5. Synthesis of 46}

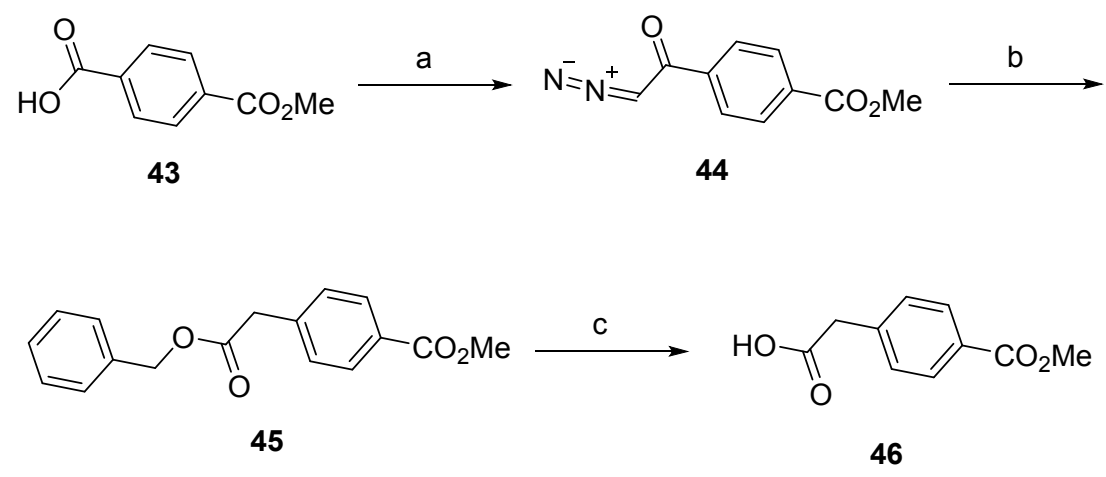


Reagents and conditions: (a) $\mathrm{SOCl}_{2}, \mathrm{DMF}, \mathrm{CH}_{2} \mathrm{Cl}_{2}, 40{ }^{\circ} \mathrm{C}$ then $\mathrm{TMSCHN}_{2}$, THF, $0{ }^{\circ} \mathrm{C}$ to rt, $62 \%$; (b) AgOAc, $\mathrm{Et}_{3} \mathrm{~N}, \mathrm{BnOH}, 60{ }^{\circ} \mathrm{C}, 88 \%$; (c) $\mathrm{H}_{2}, \mathrm{Pd} / \mathrm{C}, \mathrm{EtOH}, \mathrm{rt}, 93 \%$.

\section{Methyl 4-(diazoacetyl)benzoate (44)}

To a suspension of $43(2.5 \mathrm{~g}, 13.9 \mathrm{mmol})$ in $\mathrm{CH}_{2} \mathrm{Cl}_{2}(130 \mathrm{~mL}), 5$ drops of DMF and $\mathrm{SOCl}_{2}(5.1 \mathrm{~mL}, 69.4 \mathrm{mmol})$ were added. After the reaction mixture was stirred at $40{ }^{\circ} \mathrm{C}$ for 3.5 hours, the mixture was concentrated under reduced pressure. The remaining volatiles were azeotropically removed with EtOAc and toluene to give the corresponding acid chloride as a crude product. To a solution of $\mathrm{TMSCHN}_{2}(2.0 \mathrm{M}$ in hexanes, $13.9 \mathrm{~mL}, 27.8 \mathrm{mmol})$ in THF/MeCN $(47 \mathrm{~mL}, 1 / 1)$, the crude acid chloride in $\mathrm{THF} / \mathrm{MeCN}(30 \mathrm{~mL}, 1 / 1)$ was added at $0{ }^{\circ} \mathrm{C}$. After the reaction mixture was stirred at room temperature overnight, the mixture was concentrated under reduced pressure. The residue was purified by column chromatography ( $n$-hexane:EtOAc $=90: 10$ to $70: 30)$ to give an yellow solid. After the solid was washed with $n$-hexane, the resulting powder was filtered and dried to give $44(1.75 \mathrm{~g}, 8.62 \mathrm{mmol})$ in $62 \%$ yield. TLC: Rf 0.24 ( $n$-hexane:EtOAc $=80: 20) ;{ }^{1} \mathrm{H}-\mathrm{NMR}\left(\mathrm{CDCl}_{3}\right): \delta 3.95(\mathrm{~s}, 3 \mathrm{H}), 5.93(\mathrm{~s}, 1 \mathrm{H}), 7.81(\mathrm{~d}, J=$ $8.4 \mathrm{~Hz}, 2 \mathrm{H}), 8.11(\mathrm{~d}, J=8.4 \mathrm{~Hz}, 2 \mathrm{H})$.

\section{Methyl 4-[2-(benzyloxy)-2-oxoethyl]benzoate (45)}

To a solution of $44(1.75 \mathrm{~g}, 8.57 \mathrm{mmol})$ and $\mathrm{Et}_{3} \mathrm{~N}(2.4 \mathrm{~mL}, 17.1 \mathrm{mmol})$ in $\mathrm{BnOH}(12.6$ $\mathrm{mL}$ ), AgOAc (72 mg, $0.43 \mathrm{mmol}$ ) was added. After the mixture was stirred at $60{ }^{\circ} \mathrm{C}$ for 2 hours, $\mathrm{AgOAc}(72 \mathrm{mg}, 0.43 \mathrm{mmol})$ was added and the mixture was stirred at $60{ }^{\circ} \mathrm{C}$ for another 30 minutes. The mixture was cooled to room temperature and $0.1 \mathrm{M} \mathrm{HCl}$ was added to the mixture, which was extracted with $n$-hexane/AcOEt (4/1). The organic layer was washed with $0.1 \mathrm{M} \mathrm{HCl}$ and brine, dried with anhydrous $\mathrm{Na}_{2} \mathrm{SO}_{4}$ and concentrated under reduced pressure. The residue was purified by column chromatography ( $n$-hexane:EtOAc $=100: 0$ to $90: 10$ to $85: 15)$ to give $45(2.15 \mathrm{~g}, 7.54$ 
mmol) in $88 \%$ yield. TLC: Rf 0.38 ( $n$-hexane:EtOAc $=80: 20) ;{ }^{1} \mathrm{H}-\mathrm{NMR}\left(\mathrm{CDCl}_{3}\right): \delta$ $3.73(\mathrm{~s}, 2 \mathrm{H}), 3.91(\mathrm{~s}, 3 \mathrm{H}), 5.14(\mathrm{~s}, 2 \mathrm{H}), 7.27-7.40(\mathrm{~m}, 7 \mathrm{H}), 7.96-8.03(\mathrm{~m}, 2 \mathrm{H})$.

\section{[4-(methoxycarbonyl)phenyl]acetic acid (46)}

The suspension of 45 (2.14 g, $7.53 \mathrm{mmol})$ and 5\% $\mathrm{Pd} / \mathrm{C}$ (50\% wet, $214 \mathrm{mg})$ in $\mathrm{EtOH}$ $(45 \mathrm{~mL})$ was stirred at room temperature for 5 hours under atmosphere of hydrogen. After the catalyst was filtered off using Celite, the residue was concentrated under reduced pressure to give 46 (1.36 g, $7.00 \mathrm{mmol})$ in 93\% yield. ${ }^{1} \mathrm{H}-\mathrm{NMR}\left(\mathrm{CDCl}_{3}\right): \delta 3.72$ (s, 2H), $3.91(\mathrm{~s}, 3 \mathrm{H}), 7.36(\mathrm{~d}, J=8.6 \mathrm{~Hz}, 2 \mathrm{H}), 8.00(\mathrm{~d}, J=8.6 \mathrm{~Hz}, 2 \mathrm{H})$.

\section{Scheme 6. Synthesis of 49a and 49b}

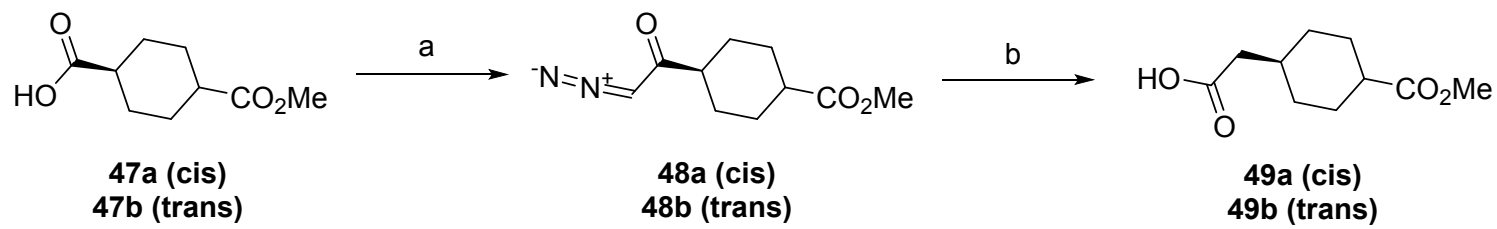

Reagents and conditions: (a) $\mathrm{SOCl}_{2}$, EtOAc, $60{ }^{\circ} \mathrm{C}$ then $\mathrm{TMSCHN}_{2}, \mathrm{THF} / \mathrm{MeCN}, 0{ }^{\circ} \mathrm{C}$ to rt, $78-81 \%$; (b) $\mathrm{CF}_{3} \mathrm{CO}_{2} \mathrm{Ag}, \mathrm{Et}_{3} \mathrm{~N}, \mathrm{THF} / \mathrm{H}_{2} \mathrm{O},-25{ }^{\circ} \mathrm{C}$ to rt, $87-100 \%$.

\section{Methyl cis-4-(diazoacetyl)cyclohexanecarboxylate (48a)}

To a suspension of $\mathbf{4 7 a}(1.86 \mathrm{~g}, 10.0 \mathrm{mmol})$ in EtOAc $(1.5 \mathrm{~mL})$, thionyl chloride (1.46 $\mathrm{mL}, 20.0 \mathrm{mmol}$ ) was added and the reaction mixture was stirred at $60{ }^{\circ} \mathrm{C}$ for 5.5 hours. After the mixture was cooled to room temperature, the mixture was concentrated under reduced pressure. The remaining volatiles were azeotropically removed with EtOAc (two times) to give the corresponding acid chloride as a crude product. To a solution of $\mathrm{TMSCHN}_{2}(2.0 \mathrm{M}$ in hexanes, $10 \mathrm{~mL}, 20.0 \mathrm{mmol})$ in THF/MeCN $(40 \mathrm{~mL}, 1 / 1)$, the crude acid chloride in THF $(5 \mathrm{~mL})$ was added at $0{ }^{\circ} \mathrm{C}$. After the reaction mixture was stirred at room temperature overnight, acetic acid $(0.86 \mathrm{~mL})$ and $\mathrm{H}_{2} \mathrm{O}(9 \mathrm{~mL})$ were added to the mixture. Organic solvents were removed under reduced pressure and 
EtOAc was added to the mixture. The mixture was washed with aqueous saturated $\mathrm{NaHCO}_{3}$ and brine, dried with anhydrous $\mathrm{Na}_{2} \mathrm{SO}_{4}$ and concentrated under reduced pressure. The residue was purified by column chromatography ( $n$-hexane:EtOAc $=$ $80: 20$ to $65: 35$ to $50: 50)$ to give $48 \mathrm{a}(1.70 \mathrm{~g}, 8.09 \mathrm{mmol})$ in $81 \%$ yield. TLC: Rf 0.44 $(n$-hexane:EtOAc $=2: 1) ;{ }^{1} \mathrm{H}-\mathrm{NMR}\left(\mathrm{CDCl}_{3}\right): \delta 1.52-1.79(\mathrm{~m}, 6 \mathrm{H}), 2.00-2.16(\mathrm{~m}, 2 \mathrm{H})$, 2.26-2.42 (m, 1H), 2.50-2.60 (m, 1H), $3.69(\mathrm{~s}, 3 \mathrm{H}), 5.30(\mathrm{~s}, 1 \mathrm{H})$.

\section{[cis-4-(methoxycarbonyl)cyclohexyl]acetic acid (49a)}

To a solution of $48 \mathrm{a}(1.70 \mathrm{~g}, 8.09 \mathrm{mmol})$ in $\mathrm{THF} / \mathrm{H}_{2} \mathrm{O}(35.2 \mathrm{~mL}, 10 / 1), \mathrm{CF}_{3} \mathrm{CO}_{2} \mathrm{Ag}(89$ $\mathrm{mg}, 0.41 \mathrm{mmol})$ in $\mathrm{Et}_{3} \mathrm{~N}(3.40 \mathrm{~mL}, 24.3 \mathrm{mmol})$ was added at $-25{ }^{\circ} \mathrm{C}$. The reaction mixture was gradually warmed to room temperature and the mixture was stirred overnight. After THF was removed under reduced pressure, $t$-BuOMe was added to the residue. The resulting mixture was filtered with Celite and extracted with aqueous saturated $\mathrm{NaHCO}_{3} .5 \mathrm{M} \mathrm{HCl}$ was added to the obtained aqueous layer and it was extracted with EtOAc (two times). The combined organic layers were washed with $\mathrm{H}_{2} \mathrm{O}$ and brine, dried with anhydrous $\mathrm{Na}_{2} \mathrm{SO}_{4}$ and concentrated under reduced pressure to give 49a $(1.40 \mathrm{~g}, 6.99 \mathrm{mmol})$ in $87 \%$ yield. ${ }^{1} \mathrm{H}-\mathrm{NMR}\left(\mathrm{CDCl}_{3}\right): \delta 1.25-1.40(\mathrm{~m}, 2 \mathrm{H})$, 1.50-1.74 (m, 4H), 1.87-2.07 (m, 3H), $2.30(\mathrm{~d}, J=7.3 \mathrm{~Hz}, 2 \mathrm{H}), 2.51-2.61(\mathrm{~m}, 1 \mathrm{H}), 3.69$ $(\mathrm{s}, 3 \mathrm{H})$.

$48 \mathrm{~b}$ and $49 \mathrm{~b}$ were synthesized in the same procedure.

Methyl trans-4-(diazoacetyl)cyclohexanecarboxylate (48b)

TLC: Rf 0.40 (n-hexane:EtOAc $=2: 1)$; ${ }^{1} \mathrm{H}-\mathrm{NMR}\left(\mathrm{CDCl}_{3}\right): \delta 1.36-1.58(\mathrm{~m}, 4 \mathrm{H})$, 1.85-1.99 (m, 2H), 2.00-2.12 (m, 2H), 2.13-2.37 (m, 2H), $3.67(\mathrm{~s}, 3 \mathrm{H}), 5.26(\mathrm{~s}, 1 \mathrm{H})$.

[trans-4-(methoxycarbonyl)cyclohexyl]acetic acid (49b) 
${ }^{1} \mathrm{H}-\mathrm{NMR}\left(\mathrm{CDCl}_{3}\right): \delta \quad 0.95-1.13(\mathrm{~m}, 2 \mathrm{H}), 1.38-1.56(\mathrm{~m}, 2 \mathrm{H}), 1.71-2.07(\mathrm{~m}, 5 \mathrm{H})$, 2.17-2.32 (m, 3H), $3.66(\mathrm{~s}, 3 \mathrm{H})$.

\section{Scheme 7. Synthesis of 55}

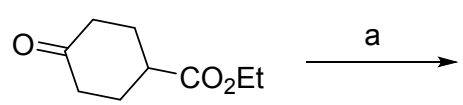

50

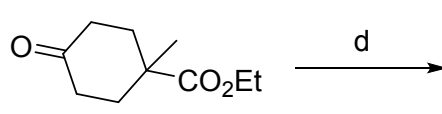

53

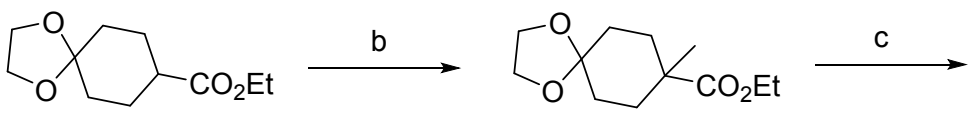

51

52

Reagents and conditions: (a) ethyleneglycol, $p-\mathrm{TsOH} \cdot \mathrm{H}_{2} \mathrm{O}$, toluene, rt; (b) $\mathrm{LDA}, \mathrm{CH}_{3} \mathrm{I}$, THF, $-30{ }^{\circ} \mathrm{C}$ to $\mathrm{rt}$; (c) $2 \mathrm{M} \mathrm{HCl}$, acetone, rt, 92\% (3 steps); (d) Meldrum's acid, $\mathrm{NaBH}(\mathrm{OAc})_{3}, \mathrm{DMF}$, rt then recrystallization, 6.9\%; (e) $\mathrm{H}_{2} \mathrm{O}, \mathrm{DMF}, 115^{\circ} \mathrm{C}, 97 \%$.

\section{Ethyl 1,4-dioxaspiro[4.5]decane-8-carboxylate (51)}

To a mixture of $\mathbf{5 0}(25.1 \mathrm{~g}, 148 \mathrm{mmol})$ in toluene $(80 \mathrm{~mL})$, ethyleneglycol $(32.2 \mathrm{~g}, 518$ mmol) and $p$-toluenesulfonic acid monohydrate (563 mg, $2.96 \mathrm{mmol})$ were added. After the reaction mixture was stirred at room temperature overnight, $n$-hexane/EtOAc (3/1) and $\mathrm{H}_{2} \mathrm{O}$ were added. The mixture was extracted and the obtained organic layer was washed with aqueous saturated $\mathrm{NaHCO}_{3}, \mathrm{H}_{2} \mathrm{O}$ and brine. The organic layer was dried with anhydrous $\mathrm{MgSO}_{4}$ and concentrated under reduced pressure to give 51 (32.1 g). The crude product was used for the next reaction without further purification. TLC: Rf $0.44(n$-hexane:EtOAc $=4: 1) .{ }^{1} \mathrm{H}-\mathrm{NMR}\left(\mathrm{CDCl}_{3}\right): \delta 1.25(\mathrm{t}, J=7.1 \mathrm{~Hz}, 3 \mathrm{H}), 1.48-1.62$ (m, 2H), 1.72-2.00 (m, 6H), 2.26-2.40 (m, 1H), 3.94 (s, 4H), 4.13 (q, $J=7.1 \mathrm{~Hz}, 2 \mathrm{H})$.

\section{Ethyl 8-methyl-1,4-dioxaspiro[4.5]decane-8-carboxylate (52)}


To a solution of LDA (2.0 M in THF/heptane/ethylbenzene, $37.5 \mathrm{~mL}, 75 \mathrm{mmol})$ in THF (50 mL), 51 (10.7 g, $49.2 \mathrm{mmol}$ from 50) in THF (12 mL) was added at $-30{ }^{\circ} \mathrm{C}$. After the mixture was stirred at $-30{ }^{\circ} \mathrm{C}$ for 20 minutes, $\mathrm{CH}_{3} \mathrm{I}(14.2 \mathrm{~g}, 100 \mathrm{mmol})$ in THF $(12 \mathrm{~mL})$ was added over 5 minutes. The reaction mixture was gradually warmed to room temperature over 1 hour and it was quenched with $\mathrm{H}_{2} \mathrm{O}$. The mixture was extracted and the obtained aqueous layer was neutralized with $2 \mathrm{M} \mathrm{HCl}$, which was extracted with EtOAc (two times). The combined organic layers were washed with $\mathrm{H}_{2} \mathrm{O}$ and brine, dried with anhydrous $\mathrm{MgSO}_{4}$ and concentrated under reduced pressure to give $52(12.8 \mathrm{~g})$. The crude product was used for the next reaction without further purification. TLC: Rf 0.51 (n-hexane:EtOAc = 4:1). ${ }^{1} \mathrm{H}-\mathrm{NMR}\left(\mathrm{CDCl}_{3}\right): \delta 1.19(\mathrm{~s}, 3 \mathrm{H})$, $1.25(\mathrm{t}, J=7.2 \mathrm{~Hz}, 3 \mathrm{H}), 1.43-1.71(\mathrm{~m}, 6 \mathrm{H}), 2.09-2.17(\mathrm{~m}, 2 \mathrm{H}), 3.93(\mathrm{~s}, 4 \mathrm{H}), 4.15(\mathrm{q}, J=$ $7.2 \mathrm{~Hz}, 2 \mathrm{H})$.

\section{Ethyl 1-methyl-4-oxocyclohexanecarboxylate (53)}

To a solution of $\mathbf{5 2}(12.8 \mathrm{~g}, 49.2 \mathrm{mmol}$ from $\mathbf{5 0})$ in acetone $(100 \mathrm{~mL}), 2 \mathrm{M} \mathrm{HCl}(50$ $\mathrm{mL}$ ) was added and the reaction mixture was stirred at room temperature overnight. Acetone was removed under reduced pressure and the resulting mixture was extracted with $t$-BuOMe. The organic layer was washed with aqueous saturated $\mathrm{NaHCO}_{3}$ and $\mathrm{H}_{2} \mathrm{O}$, dried with anhydrous $\mathrm{MgSO}_{4}$ and concentrated under reduced pressure. The residue was purified by column chromatography ( $n$-hexane:EtOAc $=98: 2$ to $91: 9$ to 80:20) to give 53 (8.34 g, $45.3 \mathrm{mmol})$ in 92\% yield (3 steps). TLC: Rf 0.41 $(n$-hexane:EtOAc $=4: 1) ;{ }^{1} \mathrm{H}-\mathrm{NMR}\left(\mathrm{CDCl}_{3}\right): \delta 1.25-1.32(\mathrm{~m}, 6 \mathrm{H}), 1.58-1.73(\mathrm{~m}, 2 \mathrm{H})$, 2.27-2.51 (m, 6H), $4.22(\mathrm{q}, J=7.2 \mathrm{~Hz}, 2 \mathrm{H})$.

Ethyl trans-4-(2,2-dimethyl-4,6-dioxo-1,3-dioxan-5-yl)-1-methylcyclohexanecarbox ylate (54) 
To a solution of 53 (30.7 g, $167 \mathrm{mmol})$ and Meldrum's acid (26.5 g, $184 \mathrm{mmol})$ in DMF $(334 \mathrm{~mL}), \mathrm{NaBH}(\mathrm{OAc})_{3}(38.9 \mathrm{~g}, 184 \mathrm{mmol})$ was added and the reaction mixture was stirred at room temperature overnight. $\mathrm{H}_{2} \mathrm{O}(2000 \mathrm{~mL})$ was added to the mixture and the resulting precipitate was filtered off to give the crude product $(34.8 \mathrm{~g})$. The crude product was recrystallized from EtOAc $(31 \mathrm{~mL})$ to give the precipitate $(8.2 \mathrm{~g}$, rich in cis isomer, cis:trans $=95: 5)$ and the filtrate $(26.8 \mathrm{~g}$ after removing EtOAc, rich in trans isomer, cis:trans $=42: 58)$. The filtrate was recrystallized from EtOAc $(31 \mathrm{~mL})$ to give the precipitate $(5.3 \mathrm{~g}$, cis:trans $=16: 84)$, which was followed by recrystallization from $n$-hexane:EtOAc $(30: 1,1428 \mathrm{~mL})$ to give $\mathbf{5 4}(3.59 \mathrm{~g}, 11.5 \mathrm{mmol})$ in $6.9 \%$ yield. TLC: Rf 0.25 (n-hexane:EtOAc $=2: 1)$; ${ }^{1} \mathrm{H}-\mathrm{NMR}\left(\mathrm{CDCl}_{3}\right): \delta 1.20-1.29(\mathrm{~m}, 6 \mathrm{H})$, $1.44-1.59(\mathrm{~m}, 2 \mathrm{H}), 1.65-1.82(\mathrm{~m}, 10 \mathrm{H}), 1.85-2.03(\mathrm{~m}, 2 \mathrm{H}), 2.32-2.46(\mathrm{~m}, 1 \mathrm{H}), 3.38(\mathrm{~d}, J$ $=3.1 \mathrm{~Hz}, 1 \mathrm{H}), 4.12(\mathrm{q}, J=7.1 \mathrm{~Hz}, 2 \mathrm{H})$.

\section{[trans-4-(ethoxycarbonyl)-4-methylcyclohexyl]acetic acid (55)}

The solution of $54(1.1 \mathrm{~g}, 3.47 \mathrm{mmol})$ in DMF $(14 \mathrm{~mL})$ and $\mathrm{H}_{2} \mathrm{O}(1.4 \mathrm{~mL})$ was stirred at $115^{\circ} \mathrm{C}$ for 4 hours. After the reaction mixture was cooled to room temperature, it was quenched with $\mathrm{H}_{2} \mathrm{O}$ and extracted with $n$-hexane/EtOAc (1/1). The organic layer was washed with brine, dried with anhydrous $\mathrm{Na}_{2} \mathrm{SO}_{4}$ and concentrated under reduced pressure to give $55(768 \mathrm{mg}, 3.37 \mathrm{mmol})$ in 97\% yield. Rf 0.20 ( $n$-hexane:EtOAc = 2:1); ${ }^{1} \mathrm{H}-\mathrm{NMR}\left(\mathrm{CDCl}_{3}\right): \delta$ 1.14-1.34 (m, 8H), 1.56-1.91 (m, 7H), $2.29(\mathrm{~d}, J=7.1 \mathrm{~Hz}$, $2 \mathrm{H}), 4.12(\mathrm{q}, J=7.1 \mathrm{~Hz}, 2 \mathrm{H})$.

\section{Scheme 8. Synthesis of 58}




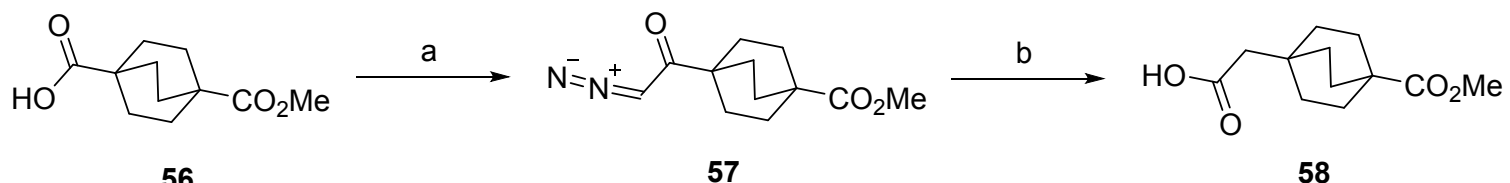
56 57 58

Reagents and conditions: (a) $\mathrm{SOCl}_{2}, \mathrm{DMF}, \mathrm{CH}_{2} \mathrm{Cl}_{2}$, rt then $\mathrm{TMSCHN}_{2}, \mathrm{THF} / \mathrm{MeCN}$, rt, $60 \%$; (b) $\mathrm{CF}_{3} \mathrm{CO}_{2} \mathrm{Ag}, \mathrm{Et}_{3} \mathrm{~N}, \mathrm{THF} / \mathrm{H}_{2} \mathrm{O}, \mathrm{rt}, 36 \%$.

\section{Methyl 4-(diazoacetyl)bicyclo[2.2.2]octane-1-carboxylate (57)}

To a suspension of $\mathbf{5 6}(1.00 \mathrm{~g}, 4.71 \mathrm{mmol})$ in $\mathrm{CH}_{2} \mathrm{Cl}_{2}(4.7 \mathrm{~mL}), \mathrm{SOCl}_{2}(0.41 \mathrm{~mL}, 5.65$ mmol) and 10 drops of DMF were added at room temperature. After the reaction mixture was stirred at room temperature for 1 hour, the mixture was concentrated under reduced pressure. The remaining volatiles were azeotropically removed with toluene to give the corresponding acid chloride as a crude mixture. To a solution of the crude acid chloride in THF/MeCN $(10 \mathrm{~mL}, 1 / 1), \mathrm{TMSCHN}_{2}(2.0 \mathrm{M}$ in hexanes, $4.71 \mathrm{~mL}, 9.42$ mmol) was added at room temperature. After the reaction mixture was stirred overnight, acetic acid was added until gas evolution ceased. The residue was concentrated under reduced pressure and purified by column chromatography ( $n$-hexane:EtOAc $=82: 18$ to 61:39). The obtained yellow oil was dissolved with $t$-BuOMe and washed with aqueous saturated $\mathrm{NaHCO}_{3}$ (three times), which was dried with anhydrous $\mathrm{MgSO}_{4}$ and concentrated under reduced pressure to give $57(661 \mathrm{mg}, 2.80 \mathrm{mmol})$ in 60\% yield. TLC: Rf 0.30 ( $n$-hexane:EtOAc $=75: 25) .{ }^{1} \mathrm{H}-\mathrm{NMR}\left(\mathrm{CDCl}_{3}\right): \delta 1.60-1.88(\mathrm{~m}, 12 \mathrm{H}), 3.65$ $(\mathrm{s}, 3 \mathrm{H}), 5.34(\mathrm{~s}, 1 \mathrm{H})$.

\section{[4-(methoxycarbonyl)bicyclo[2.2.2]oct-1-yl]acetic acid (58)}

To a suspension of $\mathrm{CF}_{3} \mathrm{CO}_{2} \mathrm{Ag}(30.0 \mathrm{mg}, 0.14 \mathrm{mmol})$ and $\mathrm{Et}_{3} \mathrm{~N}(1.15 \mathrm{~mL}, 8.28 \mathrm{mmol})$ in $\mathrm{THF} / \mathrm{H}_{2} \mathrm{O}(8.8 \mathrm{~mL}, 10 / 1), 57(652 \mathrm{mg}, 2.76 \mathrm{mmol})$ in $\mathrm{THF} / \mathrm{H}_{2} \mathrm{O}(4.4 \mathrm{~mL}, 10 / 1)$ was added dropwise at room temperature. After the reaction mixture was stirred at room temperature overnight, the catalyst was filtered off using Celite and washed by 
$t$-BuOMe. Aqueous saturated $\mathrm{NaHCO}_{3}$ was added to the filtrate and the mixture was extracted. To the resulting aqueous layer, $5 \mathrm{M} \mathrm{HCl}$ was added and the mixture was extracted with EtOAc (three times). The combined organic layers were dried with anhydrous $\mathrm{MgSO}_{4}$ and concentrated under reduced pressure to give 58 (226 mg, 1.00 mmol) in 36\% yield. TLC: Rf $0.47\left(\mathrm{CHCl}_{3}: \mathrm{MeOH}=10: 1\right) .{ }^{1} \mathrm{H}-\mathrm{NMR}\left(\mathrm{CDCl}_{3}\right): \delta$ 1.53-1.64 (m, 6H), 1.75-1.85 (m, 6H), $2.15(\mathrm{~s}, 2 \mathrm{H}), 3.63(\mathrm{~s}, 3 \mathrm{H})$.

\section{Scheme 9. Synthesis of 63}
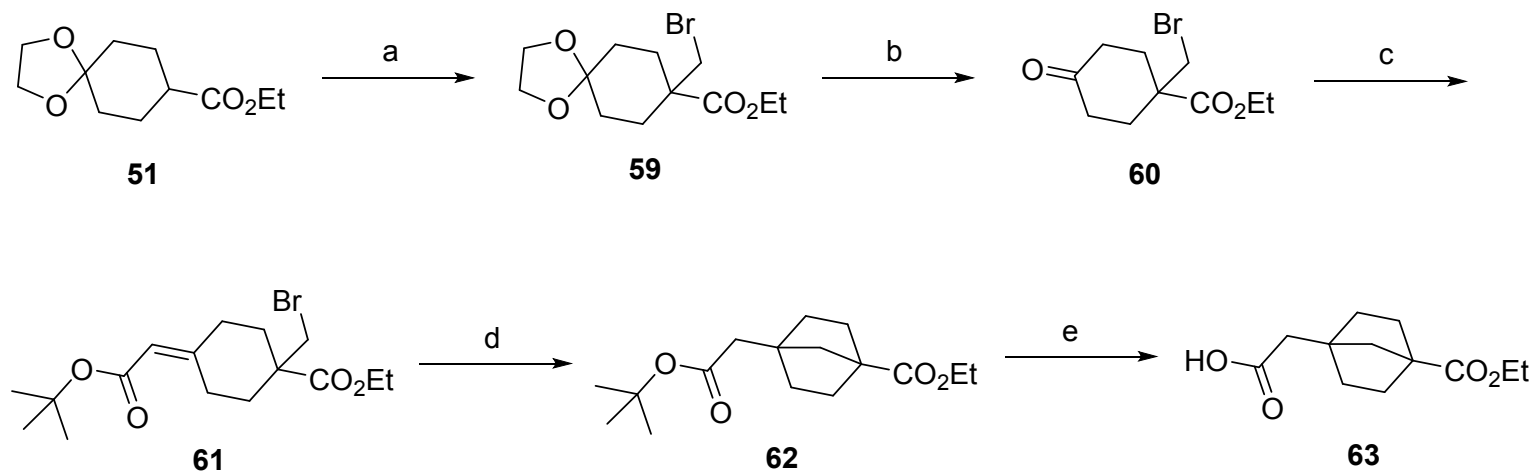

Reagents and conditions: (a) LDA, HMPA, $\mathrm{CH}_{2} \mathrm{Br}_{2}$, THF, $-74{ }^{\circ} \mathrm{C}$ to $10{ }^{\circ} \mathrm{C}$; (b) $2 \mathrm{M}$ $\mathrm{HCl}$, acetone, $50{ }^{\circ} \mathrm{C}$, 65\% (2 steps); (c) $\mathrm{NaH}$, tert-butyl dimethylphosphonoacetate, DME, $0{ }^{\circ} \mathrm{C}$ to rt, $35 \%$; (d) AIBN, $n$-Bu $3 \mathrm{SnH}$, toluene, $100{ }^{\circ} \mathrm{C}, 61 \%$; (e) TFA, $\mathrm{CH}_{2} \mathrm{Cl}_{2}$, rt, $96 \%$.

\section{Ethyl 8-(bromomethyl)-1,4-dioxaspiro[4.5]decane-8-carboxylate (59)}

To a solution of LDA (2.0 M in THF/heptane/ethylbenzene, $30.8 \mathrm{~mL}, 61.6 \mathrm{mmol}$ ) in THF $(100 \mathrm{~mL})$, HMPA $(27 \mathrm{~mL}, 155 \mathrm{mmol})$ was added at $-72{ }^{\circ} \mathrm{C}$. To the reaction mixture, 51 (12.0 g, $56.0 \mathrm{mmol})$ in THF $(50 \mathrm{~mL})$ was added dropwise at $-74{ }^{\circ} \mathrm{C}$ over 15 minutes and the mixture was stirred at $-74{ }^{\circ} \mathrm{C}$ for 30 minutes. $\mathrm{CH}_{2} \mathrm{Br}_{2}(20.1 \mathrm{~mL}, 289$ mmol) was added to the mixture at $-74{ }^{\circ} \mathrm{C}$ and the mixture was gradually warmed to 10 ${ }^{\circ} \mathrm{C}$ over 1.5 hours. The mixture was poured into $\mathrm{H}_{2} \mathrm{O}$ and it was extracted with $n$-hexane/EtOAc (1/1). The organic layer was washed with $\mathrm{H}_{2} \mathrm{O}$ (two times) and brine 
(two times), dried with anhydrous $\mathrm{Na}_{2} \mathrm{SO}_{4}$ and concentrated under reduced pressure to give 59 (18.4 g) as a crude product. The crude product contains small amounts of $\mathbf{5 1}$ and ethylbenzene and it was used for next reaction without further purification. TLC: Rf $0.45(n$-hexane:EtOAc $=4: 1) .{ }^{1} \mathrm{H}-\mathrm{NMR}\left(\mathrm{CDCl}_{3}\right): \delta 1.29(\mathrm{t}, J=7.1 \mathrm{~Hz}, 3 \mathrm{H}), 1.47-2.00$ (m, 6H), 2.18-2.38 (m, 2H), 3.49 (s, 2H), 3.90-3.96 (m, 4H), 4.21 (q, $J=7.1 \mathrm{~Hz}, 2 \mathrm{H})$.

\section{Ethyl 1-(bromomethyl)-4-oxocyclohexanecarboxylate (60)}

To a solution of 59 (4.60 g, $14.0 \mathrm{mmol}$ from 51) in acetone $(28 \mathrm{~mL}), 2 \mathrm{M} \mathrm{HCl}(14 \mathrm{~mL})$ was added. The reaction mixture was stirred at room temperature overnight and at $50{ }^{\circ} \mathrm{C}$ for 1.5 hours. After the mixture was cooled to room temperature, it was poured into aqueous saturated $\mathrm{NaHCO}_{3}$, which was extracted with $n$-hexane/EtOAc (1/1). The organic layer was washed with brine, dried with anhydrous $\mathrm{Na}_{2} \mathrm{SO}_{4}$ and concentrated under reduced pressure. The residue was purified by column chromatography ( $n$-hexane:EtOAc $=100: 0$ to $85: 15)$ to give $60(2.39 \mathrm{~g}, 9.08 \mathrm{mmol})$ in $65 \%$ yield $(2$ steps). TLC: Rf 0.34 ( $n$-hexane:EtOAc $=4: 1) ;{ }^{1} \mathrm{H}$-NMR $\left(\mathrm{CDCl}_{3}\right): \delta 1.34(\mathrm{t}, J=7.1 \mathrm{~Hz}$, $3 \mathrm{H}), 1.73-1.88(\mathrm{~m}, 2 \mathrm{H}), 2.30-2.59(\mathrm{~m}, 6 \mathrm{H}), 3.56(\mathrm{~s}, 2 \mathrm{H}), 4.29$ (q, $J=7.1 \mathrm{~Hz}, 2 \mathrm{H})$.

\section{Ethyl 1-(bromomethyl)-4-\{2-[(2-methyl-2-propanyl)oxy]-2-oxoethylidene\} cyclohex anecarboxylate (61)}

To a suspension of sodium hydride (60 wt\% in mineral oil, $396 \mathrm{mg}, 9.90 \mathrm{mmol}$ ) in DME (17 mL), tert-butyl dimethylphosphonoacetate (1.86 mL, $9.39 \mathrm{mmol})$ in DME (1 $\mathrm{mL}$ ) was added at $0{ }^{\circ} \mathrm{C}$. After the reaction mixture was stirred at room temperature for 1 hour, 60 (2.39 g, $9.08 \mathrm{mmol})$ in DME $(1 \mathrm{~mL})$ was added at $0{ }^{\circ} \mathrm{C}$. After the mixture was stirred at room temperature overnight, the phosphonate prepared from sodium hydride (60 wt\% in mineral oil, $160 \mathrm{mg}, 4.00 \mathrm{mmol}$ ) and tert-butyl dimethylphosphonoacetate $(0.75 \mathrm{~mL}, 3.79 \mathrm{mmol})$ in $\operatorname{DME}(1 \mathrm{~mL})$ as above was added at $0{ }^{\circ} \mathrm{C}$. The reaction mixture was stirred at room temperature for 1.5 hours and it was poured into $\mathrm{H}_{2} \mathrm{O}$, 
which was extracted with $n$-hexane/EtOAc (1/1). The aqueous layer was extracted with EtOAc and the combined organic layers were washed with brine, dried with anhydrous $\mathrm{Na}_{2} \mathrm{SO}_{4}$ and concentrated under reduced pressure. The residue was purified by column chromatography ( $n$-hexane:EtOAc $=100: 0$ to $88: 12$ to $80: 20)$ to give 61 (1.15 g, 3.18 mmol) in 35\% yield. TLC: Rf 0.62 (n-hexane:EtOAc $=4: 1) ;{ }^{1} \mathrm{H}-\mathrm{NMR}\left(\mathrm{CDCl}_{3}\right): \delta 1.30$ $(\mathrm{t}, J=7.1 \mathrm{~Hz}, 3 \mathrm{H}), 1.42-1.54(\mathrm{~m}, 2 \mathrm{H}), 1.47(\mathrm{~s}, 9 \mathrm{H}), 2.14-2.41(\mathrm{~m}, 6 \mathrm{H}), 3.37-3.55(\mathrm{~m}$, 2H), 4.23 (q, $J=7.1 \mathrm{~Hz}, 2 \mathrm{H}), 5.59(\mathrm{~s}, 1 \mathrm{H})$.

\section{ethyl 4-\{2-[(2-methyl-2-propanyl)oxy]-2-oxoethyl\}bicyclo[2.2.1]heptane-1-carboxyl} ate (62)

To a solution of 61 (260 mg, $0.72 \mathrm{mmol})$ in toluene $(11 \mathrm{~mL})$, AIBN (12.0 mg, 0.07 $\mathrm{mmol})$ and $n-\mathrm{Bu}_{3} \mathrm{SnH}(0.207 \mathrm{~mL}, 0.79 \mathrm{mmol})$ in toluene $(5 \mathrm{~mL})$ were added dropwise at $100{ }^{\circ} \mathrm{C}$ over 75 minutes. After the reaction mixture was stirred at $100{ }^{\circ} \mathrm{C}$ for another 5

minutes, the mixture was cooled to room temperature. EtOAc and 5\% KF aqueous solution were added to the mixture and it was filtered using Celite. The resulting filtrate was extracted and the organic layer was washed with brine, dried with anhydrous $\mathrm{Na}_{2} \mathrm{SO}_{4}$ and concentrated under reduced pressure. The residue was purified by column chromatography ( $n$-hexane:EtOAc $=90: 10$ to $86: 14)$ to give $62(123 \mathrm{mg}, 0.44 \mathrm{mmol})$ in $61 \%$ yield. TLC: Rf 0.48 ( $n$-hexane:EtOAc $=6: 1) ;{ }^{1} \mathrm{H}-\mathrm{NMR}\left(\mathrm{CDCl}_{3}\right): \delta 1.25(\mathrm{t}, J=7.1$ $\mathrm{Hz}, 3 \mathrm{H}), 1.35-1.72(\mathrm{~m}, 8 \mathrm{H}), 1.45(\mathrm{~s}, 9 \mathrm{H}), 1.91-2.06(\mathrm{~m}, 2 \mathrm{H}), 2.41(\mathrm{~s}, 2 \mathrm{H}), 4.13$ (q, $J=$ $7.1 \mathrm{~Hz}, 2 \mathrm{H})$.

\section{[4-(ethoxycarbonyl)bicyclo[2.2.1] hept-1-yl]acetic acid (63)}

To a solution of $62(35.6 \mathrm{~g}, 126.0 \mathrm{mmol})$ in $\mathrm{CH}_{2} \mathrm{Cl}_{2}(130 \mathrm{~mL})$, TFA $(130 \mathrm{~mL})$ was added at room temperature. After the reaction mixture was stirred at room temperature for 1 hour, the mixture was concentrated under reduced pressure. The remaining volatiles were azeotropically removed with toluene to give $\mathbf{6 3}(27.5 \mathrm{~g}, 121.5 \mathrm{mmol})$ in 
96\% yield. ${ }^{1} \mathrm{H}-\mathrm{NMR}\left(\mathrm{CDCl}_{3}\right): \delta 1.25(\mathrm{t}, J=7.1 \mathrm{~Hz}, 3 \mathrm{H}), 1.45-1.75(\mathrm{~m}, 8 \mathrm{H}), 1.92-2.09$ (m, 2H), $2.56(\mathrm{~s}, 2 \mathrm{H}), 4.13$ (q, $J=7.1 \mathrm{~Hz}, 2 \mathrm{H})$. 


\section{Synthesis of Compound 1 and 3-20}

Scheme 10. Synthesis of Compound 1

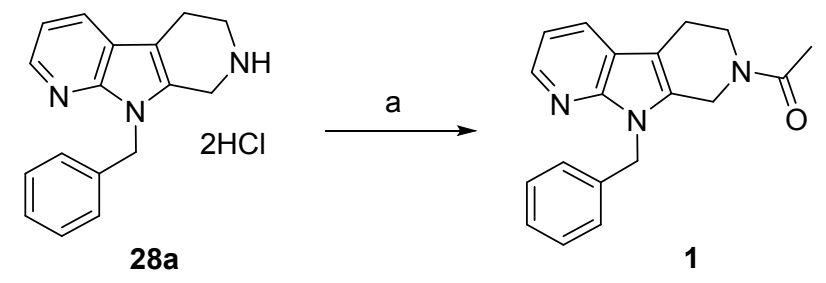

Reagents and conditions: (a) $\mathrm{Ac}_{2} \mathrm{O}$, pyridine, rt, $83 \%$.

1-(9-benzyl-5,6,8,9-tetrahydro-7H-pyrido[4',3':4,5]pyrrolo[2,3-b]pyridin-7-yl)etha none (1)

To a solution of $\mathbf{2 8 a}(150 \mathrm{mg}, 0.50 \mathrm{mmol})$ in pyridine $(1 \mathrm{~mL})$, acetic anhydride $(0.057$ $\mathrm{mL}, 0.60 \mathrm{mmol}$ ) was added. After the reaction mixture was stirred at room temperature for 1 hour, the mixture was concentrated under reduced pressure. The remaining volatiles were azeotropically removed with toluene and the residue was purified by column chromatography ( $n$-hexane:EtOAc $=83: 17$ to $75: 25$ to $50: 50$ ) to give 1 (126 $\mathrm{mg}, 0.41 \mathrm{mmol})$ in $83 \%$ yield. TLC: Rf 0.25 ( $n$-hexane:EtOAc $=1: 1) ;{ }^{1} \mathrm{H}-\mathrm{NMR}$ $\left(\mathrm{DMSO}-\mathrm{d}_{6}\right.$, the asterisk denotes minor rotamer peaks): $\delta 1.99 *$ (minor rotamer, $\mathrm{s}, 3 \mathrm{H}$ ) and 2.11 (major rotamer, s, 3H), 2.62-2.85 (m, 2H), 3.67-3.81 (m, 2H), 4.57-4.67 (m, 2H), 5.46 (major rotamer, s, 2H) and 5.49* (minor rotamer, s, 2H), 7.04-7.36 (m, 6H), 7.85-7.94 (m, 1H), 8.17-8.25 (m, 1H); ${ }^{13} \mathrm{C}-\mathrm{NMR}\left(\mathrm{DMSO}_{\mathrm{d}}\right): \delta 20.3,21.2,21.4,21.8$, $38.7,38.8,42.8,43.8,44.15,44.19,105.8,106.3$, 115.6, 118.48, 118.52, 126.0, 126.1, $126.6,126.8,127.2,127.3,128.6,128.7,132.5,132.8,138.0,138.1,142.0,142.1$, 147.67, 147.73, 169.0, 169.1; LC-MS (ELSD) $R T=0.91 \min (>99 \%)$; MS (APCI, Pos.): $m / z \mathrm{C}_{19} \mathrm{H}_{20} \mathrm{ON}_{3}(\mathrm{M}+\mathrm{H})^{+}$calc. mass 306, found 306 ; HRMS (ESI, Pos.): $m / z$ $\mathrm{C}_{19} \mathrm{H}_{20} \mathrm{ON}_{3}(\mathrm{M}+\mathrm{H})^{+}$calc. mass 306.1601 , found 306.1599 .

\section{Scheme 11. Synthesis of Compound 20}




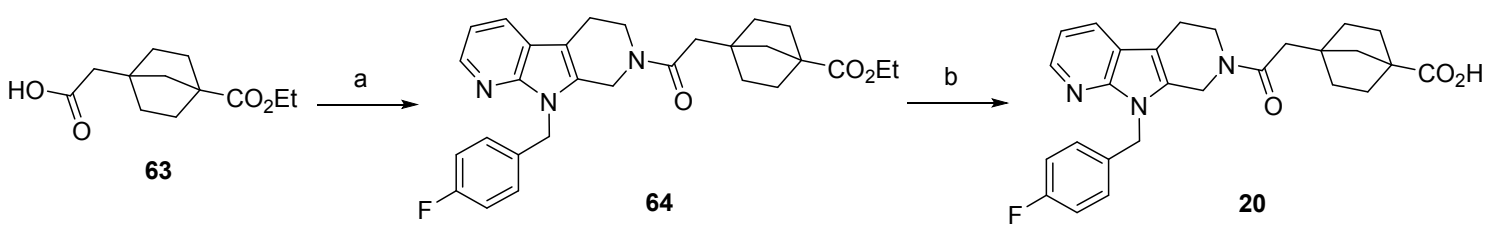

Reagents and conditions: (a) $(\mathrm{COCl})_{2}, \mathrm{DMF}, \mathrm{CH}_{2} \mathrm{Cl}_{2}$, rt then $\mathbf{2 8 d}, i-\mathrm{Pr}_{2} \mathrm{NEt}$, THF, rt, 67\%. (b) $1 \mathrm{M} \mathrm{NaOH}, \mathrm{DME}, \mathrm{MeOH}, \mathrm{rt}, 88 \%$

\section{Ethyl 4-\{2-[9-(4-fluorobenzyl)-5,6,8,9-tetrahydro-7H-pyrido[4',3':4,5]pyrrolo}

\section{[2,3-b]pyridin-7-yl]-2-oxoethyl\}bicyclo[2.2.1]heptane-1-carboxylate (64)}

To a solution of $\mathbf{6 3}(88 \mathrm{mg}, 0.39 \mathrm{mmol})$ in $\mathrm{CH}_{2} \mathrm{Cl}_{2}(2 \mathrm{~mL})$, oxalyl chloride $(0.040 \mathrm{~mL}$, $0.47 \mathrm{mmol}$ ) and 1 drop of DMF were added. After the reaction mixture was stirred at room temperature for 30 minutes, the mixture was concentrated under reduced pressure. The remaining volatiles were azeotropically removed with toluene (two times) to give the corresponding acid chloride as a crude product. To a mixture of $\mathbf{2 8 d}$ (152 $\mathrm{mg}, 0.43$ $\mathrm{mmol})$ and the crude acid chloride in THF $(10 \mathrm{~mL}), i-\operatorname{Pr}_{2} \mathrm{NEt}(0.24 \mathrm{~mL}, 1.36 \mathrm{mmol})$ was added. After the reaction mixture was stirred at room temperature for 1 hour, the mixture was quenched with $\mathrm{H}_{2} \mathrm{O}$ and it was extracted with EtOAc. The organic layer was washed with aqueous saturated $\mathrm{NaHCO}_{3}, 0.01 \mathrm{M} \mathrm{HCl}$ and brine. After the organic layer was dried with anhydrous $\mathrm{MgSO}_{4}$ and concentrated under reduced pressure, the residue was purified by column chromatography ( $n$-hexane:EtOAc $=53: 47$ to $32: 68$ ) to give $64(128 \mathrm{mg}, 0.26 \mathrm{mmol})$ in $67 \%$ yield. TLC: Rf 0.31 ( $n$-hexane:EtOAc $=1: 1)$; ${ }^{1} \mathrm{H}-\mathrm{NMR}\left(\mathrm{CDCl}_{3}\right.$, the asterisk denotes minor rotamer peaks): $\delta 1.20 *$ (minor rotamer, $\mathrm{t}$, $J=7.1 \mathrm{~Hz}, 3 \mathrm{H}$ ) and 1.23 (major rotamer, $\mathrm{t}, J=7.1 \mathrm{~Hz}, 3 \mathrm{H}), 1.28-1.77(\mathrm{~m}, 8 \mathrm{H})$, 1.80-2.07 (m, 2H), 2.39* (minor rotamer, s, 2H) and 2.68 (major rotamer, s, 2H), 2.75-2.90 (m, 2H), 3.72-3.94 (m, 2H), 4.06-4.16 (m, 2H), 4.46* (minor rotamer, $\mathrm{s}, 2 \mathrm{H})$ and 4.67 (major rotamer, s, 2H), 5.43 (major rotamer, s, 2H) and 5.45* (minor rotamer, $\mathrm{s}, 2 \mathrm{H}), 6.89-7.19(\mathrm{~m}, 5 \mathrm{H}), 7.75-7.86(\mathrm{~m}, 1 \mathrm{H}), 8.26-8.34(\mathrm{~m}, 1 \mathrm{H})$. 


\section{4-\{2-[9-(4-fluorobenzyl)-5,6,8,9-tetrahydro-7H-pyrido[4',3':4,5]pyrrolo[2,3-b]pyrid}

in-7-yl]-2-oxoethyl\}bicyclo[2.2.1] heptane-1-carboxylic acid (20)

To a mixture of $64(125 \mathrm{mg}, 0.26 \mathrm{mmol})$ in $\mathrm{DME} / \mathrm{MeOH}(5.2 \mathrm{~mL}, 1 / 1), 1 \mathrm{M} \mathrm{NaOH}$ (2.6 mL, $2.6 \mathrm{mmol})$ was added and the reaction mixture was stirred at $45{ }^{\circ} \mathrm{C}$ for 2 hours. After the mixture was cooled to room temperature, $1 \mathrm{M} \mathrm{HCl}(2.6 \mathrm{~mL})$ was added and it was extracted with EtOAc. The organic layer was washed with brine, dried with anhydrous $\mathrm{MgSO}_{4}$ and concentrated under reduced pressure. $\mathrm{MeCN}$ was added to the residue and the resulting powder was filtered off and dried under reduced pressure to give 20 (103 mg, $0.22 \mathrm{mmol})$ in 88\% yield. TLC: $\mathrm{Rf} 0.38\left(\mathrm{CHCl}_{3}: \mathrm{MeOH}=9: 1\right)$; ${ }^{1} \mathrm{H}-\mathrm{NMR}$ (DMSO-d $\mathrm{D}_{6}$, the asterisk denotes minor rotamer peaks): $\delta 1.18-1.92(\mathrm{~m}, 10 \mathrm{H})$, 2.48* (minor rotamer, s, 2H) and 2.65 (major rotamer, s, 2H), 2.65-2.83 (m, 2H), 3.70-3.84 (m, 2H), 4.58-4.68 (m, 2H), 5.44 (major rotamer, s, $2 \mathrm{H}$ ) and 5.48* (minor rotamer, s, 2H), 7.05-7.27 (m, 5H), 7.85-7.94 (m, 1H), 8.18-8.26 (m, 1H), $11.99(\mathrm{~s}, 1 \mathrm{H})$; ${ }^{13} \mathrm{C}-\mathrm{NMR}\left(\mathrm{DMSO}_{6}\right)$ ) $\delta$ 20.4, 21.4, 33.1, 33.2, 34.1, 34.3, 37.0, 37.3, 38.7, 43.0, 43.4, 43.5, 43.6, 46.0, 46.2, 46.4, 46.6, 51.3, 51.4, 105.8, 106.6, 115.39, 115.44, 115.5, $115.58,115.63,118.49,118.53,126.1,126.2$, 128.8, 128.9, 129.1, 129.2, 132.4, 132.8, $134.24,134.25,134.34,134.35,142.0,142.1,147.6,147.7,160.5,160.6,162.15$, 162.23, 169.9, 170.3, 176.7, 176.9; LC-MS (ELSD) $R T=1.01 \mathrm{~min}(>99 \%)$; MS (FAB, Pos.): $m / z \mathrm{C}_{27} \mathrm{H}_{29} \mathrm{O}_{3} \mathrm{~N}_{3} \mathrm{~F}(\mathrm{M}+\mathrm{H})^{+}$calc. mass 462, found 462 ; HRMS (ESI, Pos.): $m / z$ $\mathrm{C}_{27} \mathrm{H}_{29} \mathrm{O}_{3} \mathrm{~N}_{3} \mathrm{~F}(\mathrm{M}+\mathrm{H})^{+}$calc. mass 462.2187, found 462.2181.

3-7 and 16-19 were synthesized in the same procedure.

4-(9-benzyl-5,6,8,9-tetrahydro-7H-pyrido[4',3':4,5]pyrrolo[2,3-b]pyridin-7-yl)-4-ox obutanoic acid (3)

TLC: Rf $0.47\left(\mathrm{CHCl}_{3}: \mathrm{MeOH}: 28 \%\right.$ aqueous $\left.\mathrm{NH}_{3}=50: 10: 1\right) ;{ }^{1} \mathrm{H}-\mathrm{NMR}$ (DMSO-d $\mathrm{d}_{6}$, the asterisk denotes minor rotamer peaks): $\delta$ 2.37-2.46 (m, 2H), 2.61-2.72 (m, 2H), 
2.75-2.84 (m, 2H), 3.70-3.82 $(\mathrm{m}, 2 \mathrm{H}), 4.61$ (major rotamer, $\mathrm{s}, 2 \mathrm{H})$ and 4.66* (minor rotamer, s, 2H), 5.44 (major rotamer, s, 2H) and 5.49* (minor rotamer, s, 2H), 7.05-7.33 $(\mathrm{m}, 6 \mathrm{H}), 7.85-7.92(\mathrm{~m}, 1 \mathrm{H}), 8.17-8.23(\mathrm{~m}, 1 \mathrm{H}), 11.99(\mathrm{~s}, 1 \mathrm{H}) ;{ }^{13} \mathrm{C}-\mathrm{NMR}\left(\mathrm{DMSO}_{6}\right)$ : $\delta$ 20.3, 21.2, 27.6, 28.0, 28.9, 39.0, 41.8, 42.7, 44.2, 105.8, 106.3, 115.6, 118.47, 118.49, $126.0,126.1,126.7,126.8,127.3,128.7,132.4,132.7,138.0,138.2,142.0,142.1$, 147.7, 147.8, 170.4, 173.9; LC-MS (ELSD) $R T=0.88 \min (>99 \%)$; MS (FAB, Pos.): $m / z \quad \mathrm{C}_{21} \mathrm{H}_{22} \mathrm{O}_{3} \mathrm{~N}_{3}(\mathrm{M}+\mathrm{H})^{+}$calc. mass 364, found 364 ; HRMS (ESI, Pos.): $m / z$ $\mathrm{C}_{21} \mathrm{H}_{22} \mathrm{O}_{3} \mathrm{~N}_{3}(\mathrm{M}+\mathrm{H})^{+}$calc. mass 364.1656 , found 364.1654.

\section{5-(9-benzyl-5,6,8,9-tetrahydro-7H-pyrido[4',3' :4,5]pyrrolo[2,3-b]pyridin-7-yl)-5-ox opentanoic acid (4)}

TLC: Rf $0.47\left(\mathrm{CHCl}_{3}: \mathrm{MeOH}: 28 \%\right.$ aqueous $\left.\mathrm{NH}_{3}=50: 10: 1\right)$; ${ }^{1} \mathrm{H}-\mathrm{NMR}\left(\mathrm{DMSO}-\mathrm{d}_{6}\right.$, the asterisk denotes minor rotamer peaks): $\delta$ 1.54-1.80 $(\mathrm{m}, 2 \mathrm{H}), 2.12-2.56(\mathrm{~m}, 4 \mathrm{H})$, 2.62-2.85 (m, 2H), 3.66-3.83 (m, 2H), $4.62(\mathrm{~s}, 2 \mathrm{H}), 5.45$ (major rotamer, s, 2H) and 5.48* (minor rotamer, s, 2H), 7.04-7.33 (m, 6H), 7.84-7.92 (m, 1H), 8.16-8.24 (m, 1H), $12.00(\mathrm{~s}, 1 \mathrm{H}) ;{ }^{13} \mathrm{C}-\mathrm{NMR}\left(\mathrm{DMSO}_{\mathrm{d}}\right): \delta 20.1,20.2,20.3,21.3,31.7,32.1,32.86,32.93$, 38.9, 42.0, 42.9, 44.2, 105.7, 106.4, 115.6, 118.5, 126.0, 126.1, 126.7, 126.9, 127.27, $127.32,128.6,128.7,132.4,132.8,138.0,138.1,142.0,142.1,147.69,147.73,170.9$, 171.1, 174.2, 174.3; LC-MS (ELSD) $R T=0.90 \mathrm{~min}(>99 \%)$; MS (FAB, Pos.): $m / z$ $\mathrm{C}_{22} \mathrm{H}_{24} \mathrm{O}_{3} \mathrm{~N}_{3}(\mathrm{M}+\mathrm{H})^{+}$calc. mass 378 , found 378 ; HRMS (ESI, Pos.): $m / z \mathrm{C}_{22} \mathrm{H}_{24} \mathrm{O}_{3} \mathrm{~N}_{3}$ $(\mathrm{M}+\mathrm{H})^{+}$calc. mass 378.1812 , found 378.1810 .

\section{6-(9-benzyl-5,6,8,9-tetrahydro-7H-pyrido[4',3' :4,5]pyrrolo[2,3-b]pyridin-7-yl)-6-ox} ohexanoic acid (5)

TLC: Rf $0.48\left(\mathrm{CHCl}_{3}: \mathrm{MeOH}: 28 \%\right.$ aqueous $\left.\mathrm{NH}_{3}=50: 10: 1\right) ;{ }^{1} \mathrm{H}-\mathrm{NMR}$ (DMSO-d 6 , the asterisk denotes minor rotamer peaks): $\delta$ 1.33-1.60 (m, 4H), 2.10-2.48 (m, 4H), 2.62-2.85 (m, 2H), 3.65-3.85 (m, 2H), $4.61(\mathrm{~s}, 2 \mathrm{H}), 5.45$ (major rotamer, $\mathrm{s}, 2 \mathrm{H})$ and 
5.49* (minor rotamer, $\mathrm{s}, 2 \mathrm{H}), 7.03-7.36(\mathrm{~m}, 6 \mathrm{H}), 7.83-7.93(\mathrm{~m}, 1 \mathrm{H}), 8.16-8.24(\mathrm{~m}, 1 \mathrm{H})$, 11.97 (s, 1H); ${ }^{13} \mathrm{C}-\mathrm{NMR}$ (DMSO-d $\mathrm{d}_{6}$ ): $\delta$ 20.3, 21.3, 24.1, 24.17, 24.21, 24.3, 32.2, 32.5, 33.4, 33.5, 38.9, 42.1, 42.9, 44.2, 105.8, 106.4, 115.6, 118.5, 126.0, 126.1, 126.6, 126.8, 127.26, 127.31, 128.6, 132.5, 132.8, 138.0, 138.2, 141.9, 142.1, 147.68, 147.73, 171.1, 171.3, 174.36, 174.40; LC-MS (ELSD) $R T=0.92 \min (>99 \%)$; MS (FAB, Pos.): $m / z$ $\mathrm{C}_{23} \mathrm{H}_{26} \mathrm{O}_{3} \mathrm{~N}_{3}(\mathrm{M}+\mathrm{H})^{+}$calc. mass 392, found 392 ; HRMS (ESI, Pos.): $m / z \mathrm{C}_{23} \mathrm{H}_{26} \mathrm{O}_{3} \mathrm{~N}_{3}$ $(\mathrm{M}+\mathrm{H})^{+}$calc. mass 392.1969, found 392.1965.

\section{7-(9-benzyl-5,6,8,9-tetrahydro-7H-pyrido[4',3':4,5]pyrrolo[2,3-b]pyridin-7-yl)-7-ox} oheptanoic acid (6)

TLC: Rf $0.51\left(\mathrm{CHCl}_{3}: \mathrm{MeOH}: 28 \%\right.$ aqueous $\left.\mathrm{NH}_{3}=50: 10: 1\right) ;{ }^{1} \mathrm{H}-\mathrm{NMR}$ (DMSO-d $\mathrm{d}_{6}$, the asterisk denotes minor rotamer peaks): $\delta$ 1.12-1.60 (m, 6H), 2.09-2.47 (m, 4H), 2.61-2.83 (m, 2H), 3.65-3.83 (m, 2H), $4.61(\mathrm{~s}, 2 \mathrm{H}), 5.45$ (major rotamer, $\mathrm{s}, 2 \mathrm{H})$ and 5.48* (minor rotamer, s, 2H), 7.03-7.16 (m, 3H), 7.17-7.34 (m, 3H), 7.85-7.92 (m, 1H), 8.17-8.24 (m, 1H), 11.95 (s, 1H); ${ }^{13} \mathrm{C}-\mathrm{NMR}\left(\mathrm{DMSO}_{\mathrm{d}}\right.$ ): $\delta$ 20.3, 21.4, 24.3, 24.4, 24.5, $28.27,28.33,32.3,32.6,33.6,38.9,42.1,43.0,44.2,105.8,106.4,115.6,118.49$, $118.52,126.0,126.1,126.7,126.8,127.28,127.33,128.66,128.69,132.5,132.9,138.0$, $138.1,141.9,142.1,147.7,147.8,171.3,171.5,174.42,174.44$; LC-MS (ELSD) $R T=$ $0.95 \min (>99 \%)$; MS (FAB, Pos.): $m / z \mathrm{C}_{24} \mathrm{H}_{28} \mathrm{O}_{3} \mathrm{~N}_{3}(\mathrm{M}+\mathrm{H})^{+}$calc. mass 406, found 406 ; HRMS (ESI, Pos.): $m / z \mathrm{C}_{24} \mathrm{H}_{28} \mathrm{O}_{3} \mathrm{~N}_{3}(\mathrm{M}+\mathrm{H})^{+}$calc. mass 406.2125, found 406.2121.

\section{6-[9-(3-fluorobenzyl)-5,6,8,9-tetrahydro-7H-pyrido[4',3' :4,5]pyrrolo[2,3-b]pyridin-}

\section{7-yl]-6-oxohexanoic acid (7)}

TLC: Rf $0.43\left(\mathrm{CHCl}_{3}: \mathrm{MeOH}: \mathrm{H}_{2} \mathrm{O}=50: 10: 1\right) ;{ }^{1} \mathrm{H}-\mathrm{NMR}$ (DMSO- $\mathrm{d}_{6}$, the asterisk denotes minor rotamer peaks): $\delta$ 1.31-1.66 (m, 4H), 2.09-2.48 (m, 4H), 2.57-2.89 (m, 2H), 3.63-3.89 $(\mathrm{m}, 2 \mathrm{H}), 4.62$ (major rotamer, $\mathrm{s}, 2 \mathrm{H}$ ) and 4.64* (minor rotamer, s, 2H), 5.47 
(major rotamer, s, $2 \mathrm{H}$ ) and 5.50* (minor rotamer, s, $2 \mathrm{H}), 6.85-7.15(\mathrm{~m}, 4 \mathrm{H}), 7.26-7.40$ (m, 1H), 7.84-7.94 (m, 1H), 8.16-8.25 (m, 1H), $11.93(\mathrm{~s}, 1 \mathrm{H}) ;{ }^{13} \mathrm{C}-\mathrm{NMR}\left(\mathrm{DMSO}_{6}\right)$ : $\delta$ $20.3,21.3,24.1,24.18,24.22,24.3,32.2,32.5,33.4,33.5,38.8,42.0,42.9,43.7,106.0$, $106.6,113.4,113.5,113.6,113.7,114.1,114.2,115.7,118.6,122.62,122.63,122.79$, $122.80,126.1,126.2,130.7,130.8,132.4,132.8,140.98,141.03,141.09,141.13,142.0$, $142.1,147.6,147.7,161.4,163.0,171.2,171.4$, 174.36, 174.41; LC-MS (ELSD) $R T=$ 0.96 min (>99\%); MS (FAB, Pos.): $m / z \mathrm{C}_{23} \mathrm{H}_{25} \mathrm{O}_{3} \mathrm{~N}_{3} \mathrm{~F}(\mathrm{M}+\mathrm{H})^{+}$calc. mass 410 , found 410 ; HRMS (ESI, Pos.): $m / z \quad \mathrm{C}_{23} \mathrm{H}_{25} \mathrm{O}_{3} \mathrm{~N}_{3} \mathrm{~F}(\mathrm{M}+\mathrm{H})^{+}$calc. mass 410.1874, found 410.1871 .

trans-4-\{2-[9-(2,4-difluorobenzyl)-5,6,8,9-tetrahydro-7H-pyrido[4',3':4,5]pyrrolo[2, 3-b]pyridin-7-yl]-2-oxoethyl\}-1-methylcyclohexanecarboxylic acid (16)

TLC: Rf 0.54 ( $n$-hexane:EtOAc $=1: 2) ;{ }^{1} \mathrm{H}-\mathrm{NMR}\left(\right.$ DMSO-d $_{6}$, the asterisk denotes minor rotamer peaks): $\delta 1.08^{*}$ (minor rotamer, s, 3H) and 1.12 (major rotamer, s, 3H), $1.03-1.32(\mathrm{~m}, 2 \mathrm{H}), 1.41-1.80(\mathrm{~m}, 7 \mathrm{H}), 2.20-2.45(\mathrm{~m}, 2 \mathrm{H}), 2.65-2.84(\mathrm{~m}, 2 \mathrm{H}), 3.72-3.86$ $(\mathrm{m}, 2 \mathrm{H}), 4.63-4.72(\mathrm{~m}, 2 \mathrm{H}), 5.46$ (major rotamer, $\mathrm{s}, 2 \mathrm{H})$ and 5.52* (minor rotamer, $\mathrm{s}$, 2H), 6.82-7.05 (m, 2H), 7.10 (dd, $J=7.9,4.8 \mathrm{~Hz}, 1 \mathrm{H}), 7.24-7.36(\mathrm{~m}, 1 \mathrm{H}), 7.91(\mathrm{dd}, J=$ 7.8, $1.4 \mathrm{~Hz}, 1 \mathrm{H}), 8.21(\mathrm{dd}, J=4.8,1.5 \mathrm{~Hz}, 1 \mathrm{H}), 12.02(\mathrm{~s}, 1 \mathrm{H}) ;{ }^{13} \mathrm{C}-\mathrm{NMR}\left(\mathrm{DMSO}_{6}\right): \delta$ 20.4, 20.8, 21.5, 27.3, 32.8, 33.3, 33.4, 37.91, 37.93, 38.08, 38.10, 38.6, 38.7, 40.6, 40.7, 42.2, 43.1, 103.9, 104.0, 104.2, 106.0, 106.7, 111.7, 111.9, 115.7, 118.6, 121.05, 121.07, $121.15,121.17,121.21,121.29,121.31,126.1,126.2,129.9,129.97,130.00,130.04$ $130.10,130.14,130.17,130.20,132.4,132.8,142.0,142.1,147.6,147.7,158.75$, $158.84,160.4,160.5,160.7,160.8,162.4,162.5,170.6,170.8,179.37,179.43$; LC-MS (ELSD) $R T=1.06 \min (>99 \%)$; $\mathrm{MS}(\mathrm{FAB}, \mathrm{Pos}):. m / z \mathrm{C}_{27} \mathrm{H}_{30} \mathrm{O}_{3} \mathrm{~N}_{3} \mathrm{~F}_{2}(\mathrm{M}+\mathrm{H})^{+}$calc. mass 482, found 482 ; HRMS (ESI, Pos.): $m / z \mathrm{C}_{27} \mathrm{H}_{30} \mathrm{O}_{3} \mathrm{~N}_{3} \mathrm{~F}_{2}(\mathrm{M}+\mathrm{H})^{+}$calc. mass 482.2250, found 482.2248 . 


\section{4-\{2-[9-(2,4-difluorobenzyl)-5,6,8,9-tetrahydro-7H-pyrido[4',3' :4,5]pyrrolo[2,3-b]p}

yridin-7-yl]-2-oxoethyl\}bicyclo[2.2.2]octane-1-carboxylic acid (17)

TLC: Rf $0.49\left(\mathrm{CHCl}_{3}: \mathrm{MeOH}=10: 1\right) ;{ }^{1} \mathrm{H}-\mathrm{NMR}\left(\mathrm{DMSO}_{6}\right.$, the asterisk denotes minor rotamer peaks): $\delta 1.28-1.72(\mathrm{~m}, 12 \mathrm{H}), 2.12 *$ (minor rotamer, s, 2H) and 2.27 (major rotamer, s, $2 \mathrm{H}), 2.63-2.82(\mathrm{~m}, 2 \mathrm{H}), 3.72-3.85(\mathrm{~m}, 2 \mathrm{H}), 4.66(\mathrm{~s}, 2 \mathrm{H}), 5.46$ (major rotamer, $\mathrm{s}, 2 \mathrm{H}$ ) and 5.52* (minor rotamer, s, 2H), 6.90-7.16 (m, 3H), 7.24-7.40 (m, $1 \mathrm{H})$, 7.86-7.94 (m, 1H), 8.16-8.26 (m, 1H), $11.94(\mathrm{~s}, 1 \mathrm{H}) ;{ }^{13} \mathrm{C}-\mathrm{NMR}\left(\mathrm{DMSO}-\mathrm{d}_{6}\right): \delta 20.5$, 21.5, 28.00, 28.04, 28.1, 29.87, 29.94, 30.1, 30.9, 31.0, 37.4, 37.5, 37.89, 37.91, 37.97, $38.00,38.5,39.0,42.1,42.5,43.1,43.9,103.9$, 104.0, 104.06, 104.12, 104.2, 104.3, 105.9, 106.8, 111.8, 111.9, 115.7, 118.5, 118.6, 121.05, 121.07, 121.15, 121.17, 121.25, $121.27,126.1,126.2,130.16,130.20,130.23,130.3,130.4,130.48,130.51,130.6$, $132.3,132.8,142.0,142.1,147.6,158.76,158.84,160.4,160.5,160.7,160.8,162.4$, 162.5, 169.4, 169.9, 178.7, 178.8; LC-MS (ELSD) $R T=1.04 \min (>99 \%)$; MS (FAB, Pos.): $m / z \mathrm{C}_{28} \mathrm{H}_{30} \mathrm{O}_{3} \mathrm{~N}_{3} \mathrm{~F}_{2}(\mathrm{M}+\mathrm{H})^{+}$calc. mass 494, found 494 ; HRMS (ESI, Pos.): $m / z$ $\mathrm{C}_{28} \mathrm{H}_{30} \mathrm{O}_{3} \mathrm{~N}_{3} \mathrm{~F}_{2}(\mathrm{M}+\mathrm{H})^{+}$calc. mass 494.2250, found 494.2247.

\section{4-\{2-[9-(2,4-difluorobenzyl)-5,6,8,9-tetrahydro-7H-pyrido [4',3':4,5]pyrrolo[2,3-b]p} yridin-7-yl]-2-oxoethyl\}bicyclo[2.2.1] heptane-1-carboxylic acid (18)

TLC: Rf $0.48\left(\mathrm{CHCl}_{3}: \mathrm{MeOH}=9: 1\right)$; ${ }^{1} \mathrm{H}-\mathrm{NMR}\left(\mathrm{DMSO}_{6} \mathrm{~d}_{6}\right.$, the asterisk denotes minor rotamer peaks): $\delta$ 1.25-1.69 $(\mathrm{m}, 8 \mathrm{H}), 1.70-1.91(\mathrm{~m}, 2 \mathrm{H}), 2.53 *$ (minor rotamer, $\mathrm{s}, 2 \mathrm{H}$ ) and 2.66 (major rotamer, s, 2H), 2.63-2.83 (m, 2H), 3.72-3.85 (m, 2H), 4.61-4.72 (m, $2 \mathrm{H}), 5.46$ (major rotamer, s, $2 \mathrm{H})$ and 5.51* (minor rotamer, s, 2H), 6.87-7.03 (m, 2H), $7.09(\mathrm{dd}, J=7.7,4.8 \mathrm{~Hz}, 1 \mathrm{H}), 7.22-7.33(\mathrm{~m}, 1 \mathrm{H}), 7.85-7.93(\mathrm{~m}, 1 \mathrm{H}), 8.16-8.23(\mathrm{~m}, 1 \mathrm{H})$, 11.99 (s, 1H); ${ }^{13} \mathrm{C}-\mathrm{NMR}\left(\mathrm{DMSO}_{-}\right.$): $\delta$ 20.4, 21.4, 33.1, 33.2, 34.1, 34.3, 37.0, 37.4, $37.90,37.92,38.0,38.1,38.5,39.0,42.8,43.6,46.1,46.2,46.5,46.6,51.36,51.41$, $103.88,103.91$, 104.05, 104.08, 104.2, 104.3, 105.9, 106.7, 111.71, 111.73, 111.86, $111.88,115.7,118.58,118.62$, 121.05, 121.08, 121.15, 121.18, 121.26, 121.28, 126.1, 
$126.2,130.10,130.14,130.17,130.21,130.26,130.29,130.32,132.4,132.8,142.0$, $142.1,147.6,158.75,158.84,160.4,160.5,160.7,160.8,162.4,162.5,169.9,170.3$, 176.8, 176.9; LC-MS (ELSD) $R T=1.02 \min (>99 \%) ;$ MS (FAB, Pos.): $m / z$ $\mathrm{C}_{27} \mathrm{H}_{28} \mathrm{O}_{3} \mathrm{~N}_{3} \mathrm{~F}_{2}(\mathrm{M}+\mathrm{H})^{+}$calc. mass 480, found 480 ; HRMS (ESI, Pos.): $\mathrm{m} / \mathrm{z}$ $\mathrm{C}_{27} \mathrm{H}_{28} \mathrm{O}_{3} \mathrm{~N}_{3} \mathrm{~F}_{2}(\mathrm{M}+\mathrm{H})^{+}$calc. mass 480.2093 , found 480.2088 .

\section{4-\{2-[9-(4-fluorobenzyl)-5,6,8,9-tetrahydro-7H-pyrido[4',3':4,5]pyrrolo[2,3-b]pyrid} in-7-yl]-2-oxoethyl\} bicyclo[2.2.2]octane-1-carboxylic acid (19)

TLC: Rf 0.48 (EtOAc); ${ }^{1} \mathrm{H}-\mathrm{NMR}$ (DMSO- $\mathrm{d}_{6}$, the asterisk denotes minor rotamer peaks): $\delta 1.20-1.73(\mathrm{~m}, 12 \mathrm{H}), 2.06^{*}$ (minor rotamer, s, 2H) and 2.26 (major rotamer, s, $2 \mathrm{H}$ ), 2.61-2.82 (m, 2H), 3.72-3.83 (m, 2H), 4.57-4.68 (m, 2H), 5.44 (major rotamer, s, 2H) and 5.48* (minor rotamer, s, 2H), 7.04-7.29 (m, 5H), 7.84-7.93 (m, 1H), 8.18-8.28 (m, 1H), $11.93(\mathrm{~s}, 1 \mathrm{H}) ;{ }^{13} \mathrm{C}-\mathrm{NMR}\left(\mathrm{DMSO}_{\mathrm{d}}\right): \delta 20.5,21.5,28.0,28.1,29.9,30.1,30.9$, 31.0, 37.4, 37.5, 38.7, 42.1, 42.4, 43.3, 43.4, 43.5, 43.9, 105.8, 106.6, 115.4, 115.46, $115.54,115.60,115.62,118.4,118.5,126.1,126.2,128.8,128.9,129.2,129.3,132.3$, $132.8,134.22$, 134.24, 134.32, 134.34, 142.0, 142.1, 147.6, 147.7, 160.5, 160.7, 162.1, 162.3, 169.3, 169.9, 178.6, 178.8; LC-MS (ELSD) $R T=1.03 \min (>99 \%)$; MS (FAB, Pos.): $m / z \mathrm{C}_{28} \mathrm{H}_{31} \mathrm{O}_{3} \mathrm{~N}_{3} \mathrm{~F}(\mathrm{M}+\mathrm{H})^{+}$calc. mass 476 , found 476 ; HRMS (ESI, Pos.): $m / z$ $\mathrm{C}_{28} \mathrm{H}_{31} \mathrm{O}_{3} \mathrm{~N}_{3} \mathrm{~F}(\mathrm{M}+\mathrm{H})^{+}$calc. mass 476.2344, found 476.2340.

\section{Scheme 12. Synthesis of Compound 9}

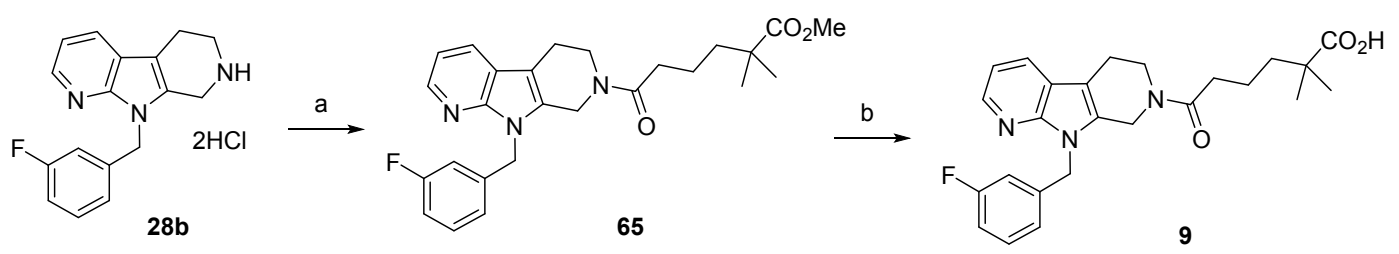

Reagents and conditions: (a) 33, EDC $\cdot \mathrm{HCl}, \mathrm{HOBt} \cdot \mathrm{H}_{2} \mathrm{O}, \mathrm{Et}_{3} \mathrm{~N}, \mathrm{DMF}, \mathrm{rt}, 87 \%$. (b) $2 \mathrm{M}$ $\mathrm{NaOH}, \mathrm{DME}, \mathrm{MeOH}, 50{ }^{\circ} \mathrm{C}, 82 \%$. 


\section{Methyl 6-[9-(3-fluorobenzyl)-5,6,8,9-tetrahydro-7H-pyrido[4',3':4,5]pyrrolo[2,3-b] pyridin-7-yl]-2,2-dimethyl-6-oxohexanoate (65)}

To a mixture of $\mathbf{2 8 b}(120 \mathrm{mg}, 0.34 \mathrm{mmol})$ and 33 (77 $\mathrm{mg}, 0.41 \mathrm{mmol})$ in DMF (2.5 $\mathrm{mL}), \mathrm{EDC} \cdot \mathrm{HCl}(115 \mathrm{mg}, 0.60 \mathrm{mmol}), \mathrm{HOBt} \cdot \mathrm{H}_{2} \mathrm{O}(67 \mathrm{mg}, 0.44 \mathrm{mmol})$ and $\mathrm{Et}_{3} \mathrm{~N}(0.14$ $\mathrm{mL}, 1.01 \mathrm{mmol}$ ) were added. After the reaction mixture was stirred at room temperature for 3 hours, the mixture was quenched with $\mathrm{H}_{2} \mathrm{O}$ and aqueous saturated $\mathrm{NaHCO}_{3}$ followed by extraction with $n$-hexane/EtOAc (1/10). The organic layer was washed with $\mathrm{H}_{2} \mathrm{O}$ and brine, dried with anhydrous $\mathrm{MgSO}_{4}$ and concentrated under reduced pressure. The residue was purified by column chromatography ( $n$-hexane:EtOAc $=90: 10$ to 60:40 to $50: 50)$ to give $65(133 \mathrm{mg}, 0.29 \mathrm{mmol})$ in $87 \%$ yield. TLC: Rf 0.55 ( $n$-hexane:EtOAc $=1: 1) ;{ }^{1} \mathrm{H}-\mathrm{NMR}\left(\mathrm{CDCl}_{3}\right.$, the asterisk denotes minor rotamer peaks): $\delta 1.15^{*}$ (minor rotamer, s, 6H) and 1.18 (major rotamer, s, 6H), 1.45-1.80 (m, 4H), 2.11-2.48 (m, 2H), 2.75-2.90 $(\mathrm{m}, 2 \mathrm{H}), 3.61^{*}$ (minor rotamer, $\mathrm{s}, 3 \mathrm{H}$ ) and 3.64 (major rotamer, $\mathrm{s}, 3 \mathrm{H}$ ), 3.69-3.95 (m, 2H), 4.44* (minor rotamer, s, 2H) and 4.65 (major rotamer, s, 2H), 5.45 (major rotamer, s, 2H) and 5.47* (minor rotamer, s, 2H), 6.72-6.82 (m, 1H), 6.83-6.99 (m, 2H), 7.03-7.13 (m, 1H), 7.17-7.32 (m, 1H), 7.74-7.85 (m, 1H), 8.24-8.32 (m, 1H).

\section{6-[9-(3-fluorobenzyl)-5,6,8,9-tetrahydro-7H-pyrido[4',3' :4,5]pyrrolo[2,3-b]pyridin-} 7-yl]-2,2-dimethyl-6-oxohexanoic acid (9)

To a mixture of 65 (125 mg, $0.28 \mathrm{mmol})$ in DME/MeOH (2 mL, 1/1), $2 \mathrm{M} \mathrm{NaOH}(1$ $\mathrm{mL}, 2.0 \mathrm{mmol}$ ) was added and the reaction mixture was stirred at $50{ }^{\circ} \mathrm{C}$ overnight. After the mixture was cooled to room temperature, $2 \mathrm{M} \mathrm{HCl}(1 \mathrm{~mL})$ and brine were added to the mixture and it was extracted with EtOAc. The organic layer was washed with brine, dried with anhydrous $\mathrm{MgSO}_{4}$ and concentrated under reduced pressure. $i-\mathrm{Pr}_{2} \mathrm{O}$ was added to the residue and the resulting powder was filtered off and dried under reduced pressure to give $9(99 \mathrm{mg}, 0.23 \mathrm{mmol})$ in $82 \%$ yield. TLC: $\mathrm{Rf} 0.49\left(\mathrm{CHCl}_{3}: \mathrm{MeOH}: \mathrm{H}_{2} \mathrm{O}\right.$ $=50: 10: 1) ;{ }^{1} \mathrm{H}-\mathrm{NMR}\left(\mathrm{DMSO}-\mathrm{d}_{6}\right.$, the asterisk denotes minor rotamer peaks): $\delta 1.02^{*}$ 
(minor rotamer, s, 6H) and 1.06 (major rotamer, s, $6 \mathrm{H}), 1.32-1.53(\mathrm{~m}, 4 \mathrm{H}), 2.22-2.46$ $(\mathrm{m}, 2 \mathrm{H}), 2.62-2.84(\mathrm{~m}, 2 \mathrm{H}), 3.67-3.83(\mathrm{~m}, 2 \mathrm{H}), 4.62(\mathrm{~s}, 2 \mathrm{H}), 5.47$ (major rotamer, $\mathrm{s}, 2 \mathrm{H})$ and 5.49* (minor rotamer, $\mathrm{s}, 2 \mathrm{H}), 6.85-7.14(\mathrm{~m}, 4 \mathrm{H}), 7.27-7.39(\mathrm{~m}, 1 \mathrm{H}), 7.84-7.94(\mathrm{~m}$, 1H), 8.18-8.23 (m, 1H), $12.00(\mathrm{~s}, 1 \mathrm{H}) ;{ }^{13} \mathrm{C}-\mathrm{NMR}\left(\mathrm{DMSO}_{\mathrm{d}}\right)$ ): $\delta$ 20.2, 20.3, 20.4, 21.3, $24.85,24.92,32.8,33.1,38.8,41.1,41.2,42.0,42.9,43.7,106.0,106.6,113.4,113.5$, $113.6,113.8,114.07,114.10,114.21,114.24,115.7,118.6,122.62,122.64,122.82$, $122.84,126.1,126.2,130.7,130.8,132.5,132.8,140.98,141.03,141.08,141.13,142.0$, 142.1, 147.6, 147.7, 161.4, 163.0, 171.2, 171.3, 178.70, 178.74; LC-MS (ELSD) $R T=$ 1.04 min (>99\%); MS (FAB, Pos.): $m / z \mathrm{C}_{25} \mathrm{H}_{29} \mathrm{O}_{3} \mathrm{~N}_{3} \mathrm{~F}(\mathrm{M}+\mathrm{H})^{+}$calc. mass 438, found 438 ; HRMS (ESI, Pos.): $m / z \quad \mathrm{C}_{25} \mathrm{H}_{29} \mathrm{O}_{3} \mathrm{~N}_{3} \mathrm{~F}(\mathrm{M}+\mathrm{H})^{+}$calc. mass 438.2187, found 438.2184 .

8 and 10-15 were synthesized in the same procedure

6-[9-(3-fluorobenzyl)-5,6,8,9-tetrahydro-7H-pyrido [4',3' :4,5]pyrrolo[2,3-b]pyridin7-yl]-3,3-dimethyl-6-oxohexanoic acid (8)

TLC: Rf 0.23 (n-hexane:EtOAc $=2: 3)$; ${ }^{1} \mathrm{H}-\mathrm{NMR}\left(\mathrm{CDCl}_{3}\right.$, the asterisk denotes minor rotamer peaks): $\delta 0.99 *$ (minor rotamer, s, 6H) and 1.07 (major rotamer, s, 6H), 1.62-1.84 (m, 2H), 2.18* (minor rotamer, s, 2H) and 2.26 (major rotamer, s, 2H), 2.24-2.56 (m, 2H), 2.77-2.95 (m, 2H), 3.76-3.99 (m, 2H), 4.53* (minor rotamer, $\mathrm{s}, 2 \mathrm{H})$ and 4.67 (major rotamer, s, 2H), 5.46 (major rotamer, s, 2H) and 5.52* (minor rotamer, $\mathrm{s}, 2 \mathrm{H}), 6.73-6.83(\mathrm{~m}, 1 \mathrm{H}), 6.85-7.00(\mathrm{~m}, 2 \mathrm{H}), 7.06-7.17(\mathrm{~m}, 1 \mathrm{H}), 7.21-7.25(\mathrm{~m}, 1 \mathrm{H})$, 7.76-7.90 (m, $1 \mathrm{H}), 8.28-8.36(\mathrm{~m}, 1 \mathrm{H}) . \mathrm{CO}_{2} \mathrm{H}$ proton was not observed; ${ }^{13} \mathrm{C}-\mathrm{NMR}$ $\left(\right.$ DMSO-d $\left._{6}\right): \delta 20.3,21.4,26.8,27.0,28.1,28.3,32.1,32.3,36.6,36.7,38.9,42.1,43.0$, 43.7, 43.8, 45.0, 45.1, 106.0, 106.6, 113.4, 113.5, 113.6, 113.7, 114.06, 114.12, 114.2, $114.3,115.7,118.6,122.59,122.61,122.72,122.74,126.1,126.2,130.72,130.74$, $130.77,130.79$, 132.4, 132.8, 140.99, 141.03, 142.0, 142.2, 147.6, 147.7, 161.4, 163.0, 171.5, 171.9, 173.1, 173.2; LC-MS (ELSD) $R T=1.02 \min (>99 \%)$; MS (FAB, Pos.): 
$m / z \quad \mathrm{C}_{25} \mathrm{H}_{29} \mathrm{O}_{3} \mathrm{~N}_{3} \mathrm{~F}(\mathrm{M}+\mathrm{H})^{+}$calc. mass 438, found 438 ; HRMS (ESI, Pos.): $\mathrm{m} / \mathrm{z}$ $\mathrm{C}_{25} \mathrm{H}_{29} \mathrm{O}_{3} \mathrm{~N}_{3} \mathrm{~F}(\mathrm{M}+\mathrm{H})^{+}$calc. mass 438.2187, found 438.2185.

\section{3-\{2-[9-(3-fluorobenzyl)-5,6,8,9-tetrahydro-7H-pyrido[ $\left.4^{\prime}, 3^{\prime}: 4,5\right]$ pyrrolo[2,3-b]pyrid} in-7-yl]-2-oxoethyl\}benzoic acid (10)

TLC: Rf 0.33 (EtOAc); ${ }^{1} \mathrm{H}-\mathrm{NMR}$ (DMSO-d $\mathrm{d}_{6}$, the asterisk denotes minor rotamer peaks): $\delta$ 2.66-2.80 (m, 2H), 3.75-3.98 (m, 4H), 4.67 (major rotamer, s, $2 \mathrm{H}$ ) and 4.72* (minor rotamer, s, $2 \mathrm{H}), 5.48(\mathrm{~s}, 2 \mathrm{H}), 6.87-7.01(\mathrm{~m}, 2 \mathrm{H}), 7.01-7.17(\mathrm{~m}, 2 \mathrm{H}), 7.23-7.56(\mathrm{~m}, 3 \mathrm{H})$, 7.70-7.98 (m, 3H), 8.17-8.28 (m, 1H), $12.90(\mathrm{~s}, 1 \mathrm{H}) ;{ }^{13} \mathrm{C}-\mathrm{NMR}\left(\mathrm{DMSO}_{6}\right): \delta 20.3$, 21.2, 42.4, 43.4, 43.7, 106.0, 106.4, 113.4, 113.6, 113.7, 114.1, 114.2, 115.7, 118.48 , $118.52,122.66,122.67,122.83,122.85,126.17,126.20,127.3,127.4,128.4,128.5$, $130.1,130.68,130.71,130.8,132.2,132.6,133.6,133.7,136.1,136.4,140.9,141.0$, 142.1, 142.2, 147.6, 147.7, 161.4, 163.0, 167.2, 167.3, 169.5, 169.6; LC-MS (ELSD) $R T$ $=1.01 \mathrm{~min}(>99 \%)$; MS (FAB, Pos.): $m / z \mathrm{C}_{26} \mathrm{H}_{23} \mathrm{O}_{3} \mathrm{~N}_{3} \mathrm{~F}(\mathrm{M}+\mathrm{H})^{+}$calc. mass 444, found 444 ; HRMS (ESI, Pos.): $m / z \quad \mathrm{C}_{26} \mathrm{H}_{23} \mathrm{O}_{3} \mathrm{~N}_{3} \mathrm{~F}(\mathrm{M}+\mathrm{H})^{+}$calc. mass 444.1718, found 444.1710.

\section{4-\{2-[9-(3-fluorobenzyl)-5,6,8,9-tetrahydro-7H-pyrido[4',3':4,5]pyrrolo[2,3-b]pyrid} in-7-yl]-2-oxoethyl $\}$ benzoic acid (11)

TLC: Rf 0.19 (EtOAc); ${ }^{1} \mathrm{H}-\mathrm{NMR}$ (DMSO-d 6 , the asterisk denotes minor rotamer peaks): $\delta$ 2.62-2.80 (m, 2H), 3.73-4.00 (m, 4H), 4.67 (major rotamer, s, $2 \mathrm{H}$ ) and 4.70* (minor rotamer, s, $2 \mathrm{H}), 5.47(\mathrm{~s}, 2 \mathrm{H}), 6.85-7.00(\mathrm{~m}, 2 \mathrm{H}), 7.00-7.16(\mathrm{~m}, 2 \mathrm{H}), 7.21-7.43(\mathrm{~m}, 3 \mathrm{H})$, 7.73-7.97 (m, 3H), 8.16-8.26 (m, 1H), $12.82(\mathrm{~s}, 1 \mathrm{H}) ;{ }^{13} \mathrm{C}-\mathrm{NMR}\left(\mathrm{DMSO}-\mathrm{d}_{6}\right): \delta 20.3$, 21.2, 42.5, 43.5, 43.7, 105.9, 106.5, 113.4, 113.6, 113.7, 114.1, 114.2, 115.7, 118.46, $118.50,122.67,122.69,122.81,122.82,126.18,126.22,128.88,128.92,129.2,129.3$, $129.4,130.66,130.72,130.8,132.1,132.5,140.8,140.9,141.0,141.1,142.1,142.2$, 147.6, 147.7, 161.4, 163.0, 167.1, 167.2, 169.2, 169.3; LC-MS (ELSD) $R T=1.01 \mathrm{~min}$ 
(>99\%); MS (FAB, Pos.): $m / z \mathrm{C}_{26} \mathrm{H}_{23} \mathrm{O}_{3} \mathrm{~N}_{3} \mathrm{~F}(\mathrm{M}+\mathrm{H})^{+}$calc. mass 444, found 444 ; HRMS (ESI, Pos.): $m / z \mathrm{C}_{26} \mathrm{H}_{23} \mathrm{O}_{3} \mathrm{~N}_{3} \mathrm{~F}(\mathrm{M}+\mathrm{H})^{+}$calc. mass 444.1718, found 444.1708.

\section{cis-4-\{2-[9-(3-fluorobenzyl)-5,6,8,9-tetrahydro-7H-pyrido[4',3' :4,5]pyrrolo[2,3-b]p yridin-7-yl]-2-oxoethyl $\}$ cyclohexanecarboxylic acid (12)}

TLC: Rf $0.49\left(\mathrm{CH}_{2} \mathrm{Cl}_{2}:\right.$ EtOAc:MeOH $\left.=8: 4: 1\right)$; ${ }^{1} \mathrm{H}-\mathrm{NMR}$ (DMSO-d ${ }_{6}$, the asterisk denotes minor rotamer peaks): $\delta 1.10-1.31(\mathrm{~m}, 2 \mathrm{H}), 1.34-1.60(\mathrm{~m}, 4 \mathrm{H}), 1.63-1.96(\mathrm{~m}$, $3 \mathrm{H}), 2.11-2.45(\mathrm{~m}, 3 \mathrm{H}), 2.61-2.84(\mathrm{~m}, 2 \mathrm{H}), 3.68-3.87(\mathrm{~m}, 2 \mathrm{H}), 4.63$ (s, 2H), 5.47 (major rotamer, s, 2H) and 5.51* (minor rotamer, s, $2 \mathrm{H}), 6.85-7.15(\mathrm{~m}, 4 \mathrm{H}), 7.26-7.40(\mathrm{~m}, 1 \mathrm{H})$, 7.84-7.96 (m, 1H), 8.16-8.26 (m, 1H), $12.03(\mathrm{~s}, 1 \mathrm{H}) ;{ }^{13} \mathrm{C}-\mathrm{NMR}\left(\mathrm{DMSO}-\mathrm{d}_{6}\right): \delta$ 20.3, 21.5, 25.8, 29.0, 29.1, 32.3, 32.5, 38.2, 38.6, 38.8, 39.1, 42.3, 43.1, 43.7, 105.9, 106.6, $113.4,113.5,113.6,113.7,114.0,114.1,114.2,114.3,115.7,118.6,122.64,122.65$, $122.8,126.1,126.2,130.70,130.72,130.75,130.78,132.5,132.8,140.95,141.00$, $141.05,141.10,142.0,142.1,147.6,147.7,161.39$, 161.42, 163.01, 163.04, 170.5, 170.8, 176.0, 176.1; LC-MS (ELSD) $R T=1.03 \mathrm{~min}(>99 \%)$; MS (FAB, Pos.): $\mathrm{m} / z$ $\mathrm{C}_{26} \mathrm{H}_{29} \mathrm{O}_{3} \mathrm{~N}_{3} \mathrm{~F}(\mathrm{M}+\mathrm{H})^{+}$calc. mass 450, found 450 ; HRMS (ESI, Pos.): $\mathrm{m} / \mathrm{z}$ $\mathrm{C}_{26} \mathrm{H}_{29} \mathrm{O}_{3} \mathrm{~N}_{3} \mathrm{~F}(\mathrm{M}+\mathrm{H})^{+}$calc. mass 450.2187 , found 450.2179 .

\section{trans-4-\{2-[9-(3-fluorobenzyl)-5,6,8,9-tetrahydro-7H-pyrido[4',3':4,5]pyrrolo[2,3-b} Ipyridin-7-yl]-2-oxoethyl\}cyclohexanecarboxylic acid (13)

TLC: Rf $0.45\left(\mathrm{CH}_{2} \mathrm{Cl}_{2}:\right.$ EtOAc: $\left.\mathrm{MeOH}=8: 4: 1\right) ;{ }^{1} \mathrm{H}-\mathrm{NMR}$ (DMSO-d $\mathrm{D}_{6}$, the asterisk denotes minor rotamer peaks): $\delta$ 0.73-1.37 (m, 4H), 1.45-1.92 (m, 5H), 1.94-2.36 (m, $3 \mathrm{H}), 2.62-2.85(\mathrm{~m}, 2 \mathrm{H}), 3.69-3.85(\mathrm{~m}, 2 \mathrm{H}), 4.64(\mathrm{~s}, 2 \mathrm{H}), 5.47$ (major rotamer, s, 2H) and 5.51* (minor rotamer, $\mathrm{s}, 2 \mathrm{H}), 6.85-7.17(\mathrm{~m}, 4 \mathrm{H}), 7.27-7.41(\mathrm{~m}, 1 \mathrm{H}), 7.85-7.95(\mathrm{~m}$, 1H), 8.16-8.26 (m, 1H), $11.97(\mathrm{~s}, 1 \mathrm{H}) ;{ }^{13} \mathrm{C}-\mathrm{NMR}\left(\mathrm{DMSO}_{\mathrm{d}}\right)$ ): $\delta$ 20.3, 21.5, 28.4, 28.5, 31.5, 31.6, 33.8, 33.9, 38.8, 42.27, 42.32, 42.4, 43.2, 43.7, 105.9, 106.6, 113.4, 113.5, $113.6,113.7,114.08,114.13,114.2,114.3,115.7,118.54,118.56,122.66,122.67$, 
$122.85,122.86,126.1,126.2,130.7,130.77,130.81,132.4,132.8,140.96,141.01$, $141.09,141.14,142.0,142.2,147.6,147.7,161.4,163.0,170.4,170.6,176.6,176.7$; LC-MS (ELSD) $R T=1.02 \min (>99 \%)$; $\mathrm{MS}\left(\mathrm{FAB}\right.$, Pos.): $m / z \mathrm{C}_{26} \mathrm{H}_{29} \mathrm{O}_{3} \mathrm{~N}_{3} \mathrm{~F}(\mathrm{M}+\mathrm{H})^{+}$ calc. mass 450, found 450 ; HRMS (ESI, Pos.): $m / z \mathrm{C}_{26} \mathrm{H}_{29} \mathrm{O}_{3} \mathrm{~N}_{3} \mathrm{~F}(\mathrm{M}+\mathrm{H})^{+}$calc. mass 450.2187, found 450.2181 .

cis-4-\{2-[9-(2,4-difluorobenzyl)-5,6,8,9-tetrahydro-7H-pyrido[4',3' :4,5]pyrrolo[2,3b]pyridin-7-yl]-2-oxoethyl\}cyclohexanecarboxylic acid (14)

TLC: Rf 0.39 (EtOAc:MeOH = 19:1); ${ }^{1} \mathrm{H}-\mathrm{NMR}\left(\mathrm{DMSO}_{6}\right.$, the asterisk denotes minor rotamer peaks): $\delta 1.08-1.31(\mathrm{~m}, 2 \mathrm{H}), 1.35-1.61(\mathrm{~m}, 4 \mathrm{H}), 1.69-1.96(\mathrm{~m}, 3 \mathrm{H}), 2.16-2.46$ $(\mathrm{m}, 3 \mathrm{H}), 2.62-2.86(\mathrm{~m}, 2 \mathrm{H}), 3.69-3.87(\mathrm{~m}, 2 \mathrm{H}), 4.65(\mathrm{~s}, 2 \mathrm{H}), 5.45$ (major rotamer, $\mathrm{s}, 2 \mathrm{H})$ and 5.51* (minor rotamer, s, 2H), 6.86-7.04 (m, 2H), 7.05-7.16 (m, 1H), 7.21-7.36 (m, 1H), 7.83-7.96 (m, 1H), 8.16-8.26 (m, 1H), $12.04(\mathrm{~s}, 1 \mathrm{H}) ;{ }^{13} \mathrm{C}-\mathrm{NMR}\left(\mathrm{DMSO}-\mathrm{d}_{6}\right): \delta 20.4$, 21.5, 25.8, 29.0, 29.1, 32.4, 32.5, 37.92, 37.94, 38.1, 38.2, 38.6, 42.1, 43.1, 103.9, 104.0, 104.2 , 106.0, 106.6, 111.68, 111.71, 111.73, 111.8, 111.85, 111.88, 115.7, 118.61, $118.63,121.05,121.07,121.15,121.17,121.27,121.29,126.1,126.2$, 130.09, 130.13, $130.16,130.19,132.5,132.8,142.0,142.1,147.59,147.62,158.7,158.8,160.4,160.5$, $160.7,160.8,162.4,162.5,170.6,170.8,176.1$; LC-MS (ELSD) $R T=1.03 \min (>99 \%)$; MS (FAB, Pos.): $m / z \mathrm{C}_{26} \mathrm{H}_{28} \mathrm{O}_{3} \mathrm{~N}_{3} \mathrm{~F}_{2}(\mathrm{M}+\mathrm{H})^{+}$calc. mass 468, found 468 ; HRMS (ESI, Pos.): $m / z \mathrm{C}_{26} \mathrm{H}_{28} \mathrm{O}_{3} \mathrm{~N}_{3} \mathrm{~F}_{2}(\mathrm{M}+\mathrm{H})^{+}$calc. mass 468.2093, found 468.2081.

trans-4-\{2-[9-(2,4-difluorobenzyl)-5,6,8,9-tetrahydro-7H-pyrido[4',3':4,5]pyrrolo[2, 3-b]pyridin-7-yl]-2-oxoethyl\} cyclohexanecarboxylic acid (15)

TLC: Rf $0.37\left(\mathrm{CH}_{2} \mathrm{Cl}_{2}:\right.$ EtOAc:MeOH = 8:4:1); ${ }^{1} \mathrm{H}-\mathrm{NMR}$ (DMSO-d ${ }_{6}$, the asterisk denotes minor rotamer peaks): $\delta$ 0.75-1.37 (m, 4H), 1.45-1.92 (m, 5H), 1.92-2.38 (m, $3 \mathrm{H}), 2.62-2.84(\mathrm{~m}, 2 \mathrm{H}), 3.68-3.84(\mathrm{~m}, 2 \mathrm{H}), 4.65(\mathrm{~s}, 2 \mathrm{H}), 5.45$ (major rotamer, s, 2H) and $5.51^{*}$ (minor rotamer, s, $\left.2 \mathrm{H}\right), 6.86-7.03(\mathrm{~m}, 2 \mathrm{H}), 7.10(\mathrm{dd}, J=7.8,4.8 \mathrm{~Hz}, 1 \mathrm{H})$, 
7.21-7.36 (m, $1 \mathrm{H}), 7.89(\mathrm{dd}, J=7.5,1.2 \mathrm{~Hz}, 1 \mathrm{H}), 8.20(\mathrm{dd}, J=4.8,1.2 \mathrm{~Hz}, 1 \mathrm{H}), 11.97$ $(\mathrm{s}, 1 \mathrm{H}) ;{ }^{13} \mathrm{C}-\mathrm{NMR}\left(\mathrm{DMSO}_{6}\right): \delta 20.4,21.5,28.48,28.53,31.54,31.59,33.8,33.9$, $37.91,37.93,38.05,38.07,38.6,42.2$, 42.28, 42.33, 43.1, 103.9, 104.1, 104.2, 106.0, $106.7,111.72$, 111.74, 111.86, 111.89, 115.7, 118.59, 118.62, 121.05, 121.07, 121.14, $121.16,121.28,121.30,126.1,126.2,130.1,130.15,130.17,130.21,132.4,132.8$, 142.0, 142.1, 147.6, 147.7, 158.7, 158.8, 160.4, 160.5, 160.7, 160.8, 162.4, 162.5, 170.4, 170.6, 176.6, 176.7; LC-MS (ELSD) $R T=1.02 \mathrm{~min}(>99 \%)$; MS (FAB, Pos.): $\mathrm{m} / z$ $\mathrm{C}_{26} \mathrm{H}_{28} \mathrm{O}_{3} \mathrm{~N}_{3} \mathrm{~F}_{2}(\mathrm{M}+\mathrm{H})^{+}$calc. mass 468, found 468 ; HRMS (ESI, Pos.): $\mathrm{m} / \mathrm{z}$ $\mathrm{C}_{26} \mathrm{H}_{28} \mathrm{O}_{3} \mathrm{~N}_{3} \mathrm{~F}_{2}(\mathrm{M}+\mathrm{H})^{+}$calc. mass 468.2093, found 468.2080. 
NMR spectra for compound 20

${ }^{1} \mathrm{H}-\mathrm{NMR}$

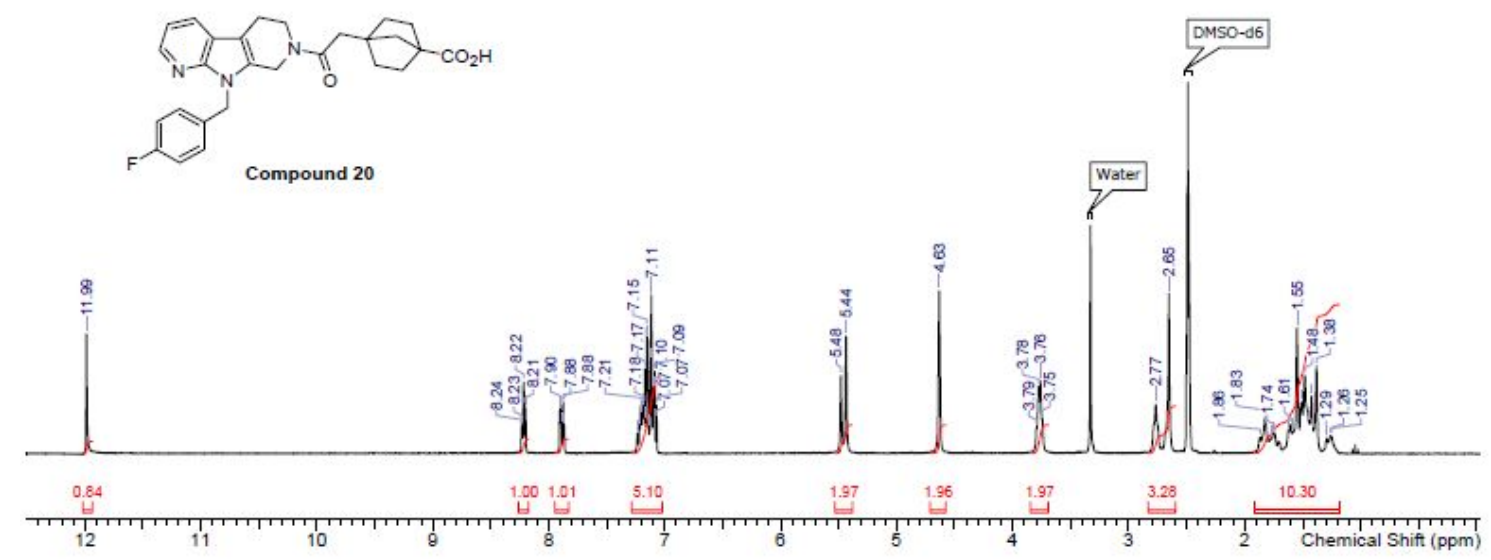

${ }^{13} \mathrm{C}-\mathrm{NMR}$
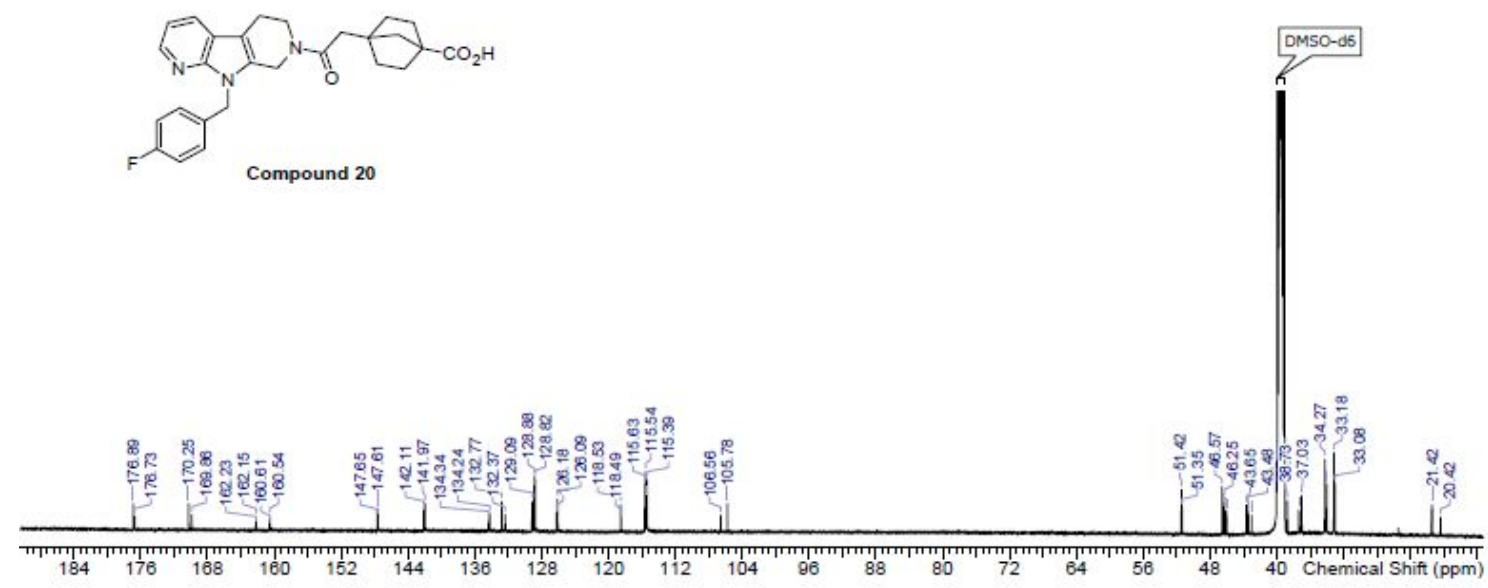


\section{Biology and DMPK}

\section{In vitro human ATX assay and human plasma LysoPLD assay}

Recombinant human ATX/ENPP2 was dissolved in $100 \mathrm{mM}$ Tris-HCl buffer (pH 9.0) containing $500 \mathrm{mM} \mathrm{NaCl}, 5 \mathrm{mM} \mathrm{MgCl}_{2}$ and $0.05 \%$ Triton $\mathrm{X}-100$. This aqueous solution of recombinant human ATX/ENPP2 (final concentration $2 \mathrm{mg} / \mathrm{ml}$ ) or human plasma (final concentration $40 \%$ ) was added to the reaction mixture containing different concentrations of the test compounds, $1 \mathrm{mM} \mathrm{16:0} \mathrm{LPC} \mathrm{and} \mathrm{1 \%} \mathrm{DMSO.} \mathrm{After} \mathrm{each}$ mixture was incubated at $37{ }^{\circ} \mathrm{C}$ for $15 \mathrm{~h}$ (primary reaction), samples of each mixture were subjected to the secondary reaction with 10 volumes of $300 \mathrm{mM}$ TOOS containg $100 \mathrm{mM}$ Tris-HCl solution $(\mathrm{pH}$ 8.5), $500 \mathrm{mM}$ 4-aminoantipyrine, $600 \mathrm{mU} / \mathrm{ml}$ horseradish peroxidase, $3 \mathrm{U} / \mathrm{ml}$ choline oxidase and $5 \mathrm{mM} \mathrm{CaCl}_{2}$ at $37{ }^{\circ} \mathrm{C}$ for $20 \mathrm{~min}$ (secondary reaction). The amount of choline released in each reaction mixture was quantified from the absorbance at $555 \mathrm{~nm}$ using a blank obtained from incubations, which did not contain enzyme solution using calibration curve created with the choline chloride standard. Measurement points of choline production were plotted against the concentration of the test compound and the theoretical curve to obtain the $\mathrm{IC}_{50}$ value of the inhibitor for human ATX activity or human plasma LysoPLD activity was obtained using the Activity Base (ID Business Solutions Ltd).

\section{Antitumor effect in a mouse model of a subcutaneously implanted human breast cancer cell line}

Human breast cancer cell line MDA-MB-231 was subcutaneously implanted into female CB17/lcr-Prkdc scid/CrlCrlj (hereinafter referred to as SCID) mice at $2.6 \times 10^{6}$ cells/mouse. Tumor diameters were measured 2 to 3 times a week from 18 days after implantation and tumor volume was calculated. 9 animals were allocated to each group to maintain a similar mean tumor volume for each group 35 days after implantation (Day 0) and drug administration was started the following day (Day 1). Paclitaxel was 
administered intraperitoneally at the maximum tolerated dose of $20 \mathrm{mg} / \mathrm{kg}$ three times weekly for 5 weeks. Compound 20 was administered orally at doses of 30 or $100 \mathrm{mg} / \mathrm{kg}$ twice daily for 32 days. Paclitaxel and compound $\mathbf{2 0}$ were administered as monotherapy or in combination. On Day 32 (final evaluation day) and Day 33, animals were autopsied, and blood and tumor samples were collected. Tumor volume and TGI median were served as evaluation indicators. Plasma LysoPLD activity was also measured using plasma samples collected at the time of the autopsy. Plasma LysoPLD activity suppression rate was calculated compared with the vehicle group.

\section{Plasma protein binding.}

The plasma protein binding of the test compounds was assessed by an equilibrium dialysis method $(\mathrm{n}=3)$. To rat or human plasma, $50 \mu \mathrm{M}$ solution $(50 \% \mathrm{MeCN}$ containing $0.5 \% \mathrm{DMSO}$ ) of the test compound was added to make a $1 \mu \mathrm{M}$ sample. Each of these samples was placed into a sample chamber of a rapid equilibrium dialysis (RED) device (Thermo Fisher Scientific). Phosphate buffered saline (PBS) was placed into a buffer chamber. After the RED device was shaken at $37^{\circ} \mathrm{C}$ and $400 \mathrm{rpm}$ for $4 \mathrm{~h}$, the sample was collected from each chamber. The test compound in each sample was assayed by LC-MS/MS analysis and the plasma protein binding was calculated.

\section{Pharmacokinetic analysis in mouse, rat, dog and monkey.}

Female SCID mice, male SD rats, male beagle dogs and male cynomolgus monkeys were used for the studies. The pharmacokinetics of the test compounds were evaluated by single intravenous (iv) and oral (po) administration $(\mathrm{n}=3)$. The iv solution formulation contained 30\% (2-Hydroxypropyl)- $\beta$-cyclodextrin and $\mathrm{NaOH}$ ( 1 equiv) while po solution formulations contained $20 \%$ wellsolve and $\mathrm{NaOH}$ ( 1 equiv). Animals were fasted prior to dosing. Plasma samples were assayed by LC-MS/MS analysis employing positive-ion Turbo IonSpray ionization. Plasma concentration-time data were analyzed by noncompartmental methods. 


\section{Pharmacokinetic analysis in rat cassette dosing.}

Male SD rats were used for the studies. The pharmacokinetics of the test compounds were evaluated by single oral administration $(n=3)$. The po solution formulations contained 1\% DMSO and 10\% wellsolve. All po formulations were given as cassette dosing solutions containing five compounds. Animals were fasted prior to oral dosing. Plasma samples were assayed by LC-MS/MS analysis employing positive-ion Turbo IonSpray ionization. Plasma concentration-time data were analyzed by noncompartmental methods.

\section{In Vitro Hepatocyte Metabolic Stability.}

The metabolic stability of the test compounds (1 $\mu \mathrm{M}$ test concentration) was determined in cryopreserved hepatocytes (Thermo Fisher Scientific). Incubations (final incubation volume $=800 \mu \mathrm{L}$ ) were performed at $37{ }^{\circ} \mathrm{C}$ under an atmosphere of $95 \% / 5 \%$ $\mathrm{CO}_{2} / \mathrm{O}_{2}$ using 1 million cells $/ \mathrm{mL}$ in hepatocyte incubation media. Then, $150 \mu \mathrm{L}$ aliquots (cells and media) were taken at $2 \mathrm{~h}$ after the start of the incubation and quenched using $300 \mu \mathrm{L}$ of $\mathrm{MeCN} / \mathrm{EtOH}(7 / 3)$. The resulting samples were centrifuged at $3000 \mathrm{~g}$ for 10 min. An aliquot $(10 \mu \mathrm{L})$ of the supernatant was directly injected onto the LC-MS/MS for analysis. All incubations were performed in duplicate.

\section{Log D determination (Absorption Systems)}

The octanol/buffer partition coefficient of the test compound was measured. The buffer was prepared by combining $50 \mathrm{~mL}$ of $0.2 \mathrm{M}$ solution of $\mathrm{KH}_{2} \mathrm{PO}_{4}$ with $150 \mathrm{~mL}$ of $\mathrm{H}_{2} \mathrm{O}$, and then adjusting to $\mathrm{pH} 7.4$ with $10 \mathrm{M} \mathrm{NaOH}$. In a single incubation, $15 \mu \mathrm{L}$ of a 10 mM DMSO solution of the test compound was added to test tubes which contained 0.75 $\mathrm{mL}$ of $n$-octanol and $0.75 \mathrm{~mL}$ of phosphate buffer. Testosterone was also introduced to each tube as an internal control at a dosing concentration of $100 \mu \mathrm{M}$. These samples 
were gently mixed on a benchtop rotator for 1 hour at room temperature. The tubes were then removed from the rotator and the aqueous and organic phases were allowed to separate for 1 hour. An aliquot of the organic layer was taken and diluted 200-fold into a mixture of buffer and $\mathrm{MeCN}(1 / 1)$. An aliquot of the aqueous layer was taken and diluted 2-fold, 10-fold, and 200-fold into a mixture of buffer and MeCN (1/1). All samples were assayed by LC-MS/MS using ESI. 